\title{
Late Eocene-early Miocene evolution of the southern Australian subtropical front: a marine palynological approach
}

\author{
Frida S. Hoem ${ }^{1}$, Isabel Sauermilch ${ }^{1}$, Suning Hou ${ }^{1}$, Henk Brinkhuis ${ }^{1,2}$, Francesca Sangiorgi ${ }^{1}$, and \\ Peter K. Bijl ${ }^{1}$ \\ ${ }^{1}$ Marine Palynology and Paleoceanography, Department of Earth Sciences, \\ Utrecht University, Utrecht, the Netherlands \\ ${ }^{2}$ Royal Netherlands Institute for Sea Research (NIOZ), Texel, the Netherlands \\ Correspondence: Frida S. Hoem (f.s.hoem@uu.nl)
}

Received: 5 July 2021 - Revised: 27 September 2021 - Accepted: 1 October 2021 - Published: 29 October 2021

\begin{abstract}
Improvements in our capability to reconstruct ancient surface-ocean conditions based on organicwalled dinoflagellate cyst (dinocyst) assemblages from the Southern Ocean provide an opportunity to better establish past position, strength and oceanography of the subtropical front (STF). Here, we aim to reconstruct the late Eocene to early Miocene (37-20 Ma) depositional and palaeoceanographic history of the STF in the context of the evolving Tasmanian Gateway as well as the potential influence of Antarctic circumpolar flow and intense waxing and waning of ice. We approach this by combining information from seismic lines (revisiting existing data and generating new marine palynological data from Ocean Drilling Program (ODP) Hole 1168A) in the western Tasmanian continental slope. We apply improved taxonomic insights and palaeoecological models to reconstruct the sea surface palaeoenvironmental evolution. Late Eocene-early Oligocene (37-30.5 Ma) assemblages show a progressive transition from dominant terrestrial palynomorphs and inner-neritic dinocyst taxa as well as cysts produced by heterotrophic dinoflagellates to predominantly outer-neritic/oceanic autotrophic taxa. This transition reflects the progressive deepening of the western Tasmanian continental margin, an interpretation supported by our new seismic investigations. The dominance of autotrophic species like Spiniferites spp. and Operculodinium spp. reflects relatively oligotrophic conditions, like those of regions north of the modern-day STF. The increased abundance in the earliest Miocene of Nematosphaeropsis labyrinthus, typical for modern subantarctic zone (frontal) conditions, indicates a cooling and/or closer proximity of the STF to the site . The absence of major shifts in dinocyst assemblages contrasts with other records in the region and suggests that small changes in surface oceanographic conditions occurred during the Oligocene. Despite the relatively southerly $\left(63-55^{\circ} \mathrm{S}\right)$ location of Site 1168, the rather stable oceanographic conditions reflect the continued influence of the proto-Leeuwin Current along the southern Australian coast as Australia continued to drift northward. The relatively "warm" dinocyst assemblages at ODP Site 1168, compared with the cold assemblages at Antarctic Integrated Ocean Drilling Program (IODP) Site U1356, testify to the establishment of a pronounced latitudinal temperature gradient in the Oligocene Southern Ocean.
\end{abstract}




\section{Introduction}

Late stages of continental break-up between Australia and Antarctica in the late Eocene-early Miocene led to gradual deepening and widening of the Tasmanian Gateway (Lawver et al., 1992; Cande and Stock, 2004; Whittaker et al., 2013). This process redirected Southern Ocean surface water circulation (Stickley et al., 2004a; Bijl et al., 2013; Sijp et al., 2014, 2016) and regionally redistributed ocean heat (Sijp et al., 2014, 2016) with notable consequences for Antarctic surface water temperatures (Houben et al., 2019; Sauermilch et al., 2021). While the general oceanographic consequences of the opening of the Tasmanian Gateway - the breakdown of gyres and the onset of a wind-driven, eastward-flowing current - are now broadly understood (Stickley et al., 2004a; Bijl et al., 2013; Hill et al., 2013; Sijp et al., 2014; Houben et al., 2019), the development of Southern Ocean frontal systems (Nelson and Cooke, 2001), such as the subtropical front (STF), and ultimately the evolution and strengthening of the Antarctic Circumpolar Current (ACC) as the gateway widens (Hill et al., 2013) are largely unexplained.

To a large extent, our knowledge on the development of Paleogene Southern Ocean surface circulation is built on biogeographic patterns in organic-walled dinoflagellate cyst assemblages (Wrenn and Beckman, 1982; Bijl et al., 2011) as well as supporting information from other microfossil groups (Pascher et al., 2015), both backed up by numerical model simulations (e.g. Huber et al., 2004; Sijp et al., 2014). Dinoflagellates are single-celled, predominantly marine, eukaryotic protists, which represent an important group of marine plankton. During their life cycle, $\sim 15 \%$ of modern dinoflagellate species produce preservable organic-walled resting cysts (dinocysts), which can be found in marine sedimentary archives (e.g. Fensome, 1993; Head, 1996). Dinocysts are increasingly and successfully used as a proxy for palaeoceanographic reconstructions in the Southern Ocean (e.g. Houben et al., 2013; Prebble et al., 2013; Bijl et al., 2018; Sangiorgi et al., 2018).

In 2000, Ocean Drilling Program (ODP) Leg 189 drilled five sites around Tasmania - on the western Tasmanian margin (Site 1168), the South Tasmanian Rise (sites 1169, 1170 and 1171) and the East Tasmanian Plateau (Site 1172) with the goal of reconstructing the timing, nature and climatic consequences of the opening of the Tasmanian Gateway (Fig. 1a; Exon et al., 2001a). Site 1168 is presently located north of the STF and contains a near-continuous sediment record of late Eocene-Quaternary age. The site is in the path of the Zeehan Current, a saline, warm surface water flowing off western Tasmania that originates from the Leeuwin Current (Ridgway and Condie, 2004). Brinkhuis et al. (2003) provided a preliminary overview of the late Eocene-Quaternary dinocyst assemblage distribution and illustrated the main trends in palynomorph distribution. The study by van Simaeys et al. (2005) detected the typical boreal taxon Svalbardella spp. in the Oligocene record of Site 1168 and showed that the species likely migrated across the Equator into the Southern Ocean in response to the inception of cold, glacial phase Oi-2b, around 27.1 Ma.

Empirical relationships between extinct species abundance and proxy data for oceanographic conditions (e.g. Wall et al., 1977; Pross and Brinkhuis, 2005; Sluijs et al., 2005; Frieling and Sluijs, 2018) have strengthened the use of dinocysts for past oceanographical reconstructions. These have been used, for example, to detect a circum-Antarctic biotic turnover across the Eocene-Oligocene transition (EOT) with the origination of a sea-ice ecosystem (Houben et al., 2013) and a shift towards upwelling-related primary productivity (Houben et al., 2019; Bijl et al., 2018) in the Southern Ocean. Meanwhile, knowledge of dinocyst ecological preferences in the modern ocean has greatly advanced in the last couple of decades (e.g. Zonneveld et al., 2013), particularly for the Southern Ocean (Prebble et al., 2013; Marret et al., 2020). These modern affinities of dinocysts have been successfully used to resolve Antarctic-proximal oceanic conditions in the Oligocene and Miocene (Sangiorgi et al., 2018; Bijl et al., 2018; building on pioneering work from studies such as Hannah et al., 2000). Moreover, recently, the tectonic history of Australian-Antarctic separation and the palaeoenvironmental consequences have been reconstructed in more detail (Whittaker et al., 2013; Williams et al., 2019; Sauermilch et al., 2019a, 2021). Together, this knowledge facilitates reinterpretation of the original shipboard reconstruction of the depositional environments at Site 1168 (Exon et al., 2001b).

Here, we revisit Site 1168 (Exon, 2001b; Brinkhuis et al., 2003; Hill and Exon, 2004) and the first results, and focus in more detail on the sediments deposited during the late Eocene-early Miocene. Integrating new interpretations of the seismo-stratigraphy, an improved integrated bio-magnetostratigraphic age model and new interpretations from high-resolution dinocyst assemblage data, we provide an updated view of the evolving depositional environment and palaeoceanographic conditions. We analyse our results in the context of those from other sites in the Australo-Antarctic Gulf (AAG) (IODP Site U1356 - Bijl et al., 2018; ODP Site 1128 and Browns Creek - Houben et al., 2019; east of Tasmania, ODP Site 1172 - Sluijs et al., 2003; in and offshore of the Ross Sea, Cape Roberts Project - Clowes et al., 2016; and Deep Sea Drilling Project, DSDP, Site 274 Hoem et al., 2021a) to build a picture of the late Eoceneearly Miocene (37-20 Ma) palaeoceanographic evolution in the region of the widening Tasmanian Gateway.

\section{Material}

\subsection{ODP Leg 189, Site 1168: site description, age model and lithology}

Ocean drilling at the western Tasmanian margin ODP Site $1168\left(42^{\circ} 38^{\prime} 40^{\prime \prime} \mathrm{S}, 144^{\circ} 25^{\prime} 30^{\prime \prime} \mathrm{E}\right.$; present-day water 


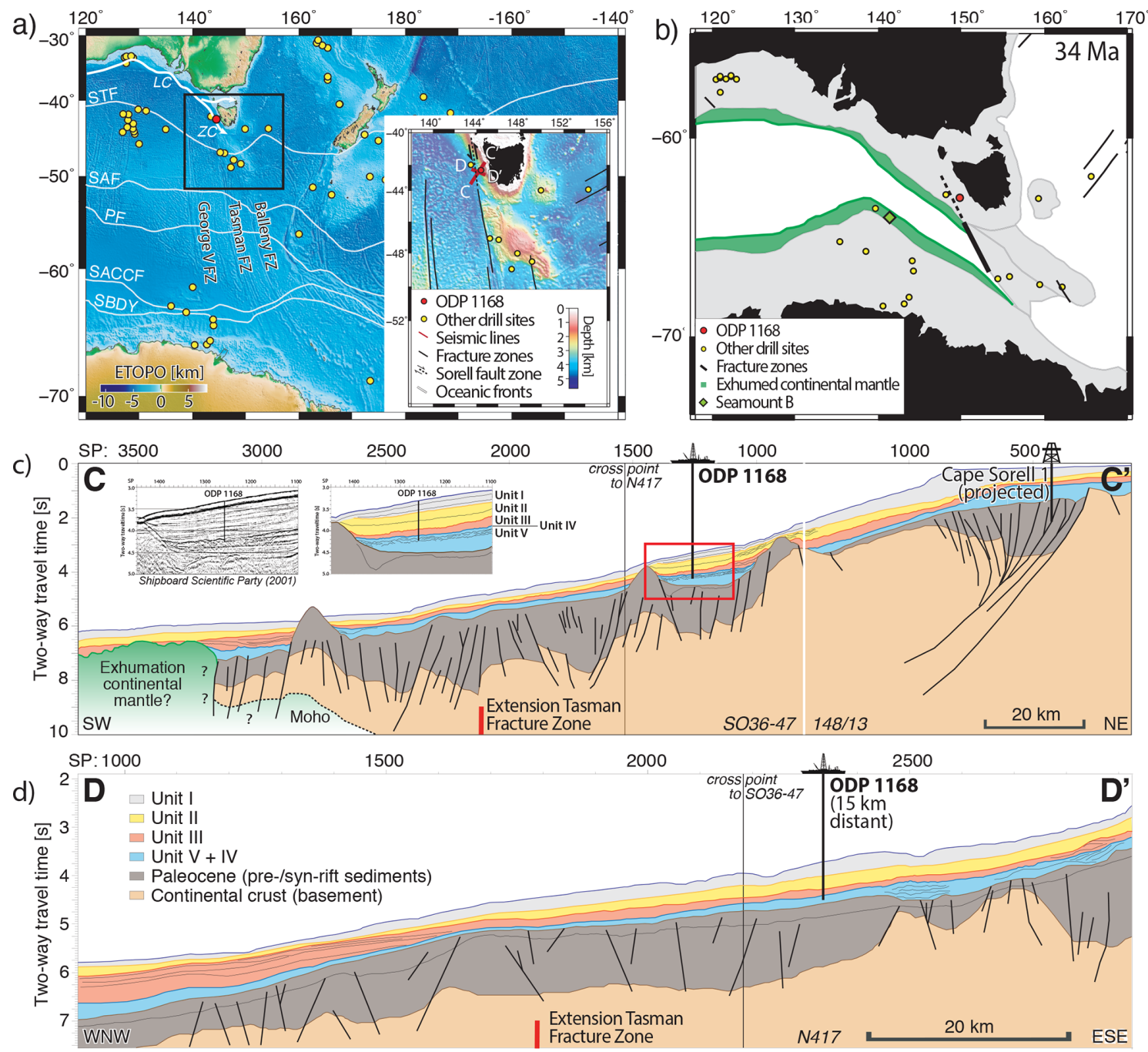

Figure 1. (a) Present-day map of the Australian sector of the Southern Ocean showing ODP Site 1168 (red dot), other drill sites mentioned in this study (yellow dots), ocean fronts (white lines; STF is the subtropical front, SAF is the subantarctic front, PF is the polar front, SACCF is the Southern Antarctic Circumpolar Current front and SBDY is the southern boundary) and southern Australian ocean currents (white arrow; LC is the Leeuwin Current and ZC is the Zeehan Current). The map uses the regional 1 min gravity-derived Earth Topography and Bathymetry map (Weatherall et al., 2015). The inset shows high-resolution shipboard bathymetry data from the study area (gaps filled with the Earth Topography and Bathymetry map) with seismic profiles presented in this study (red lines), prominent fracture zones (black lines) and the extended Sorell Fault Zone (dashed line; after Miller et al., 2002). (b) Palaeogeographic map of the Tasman region at 34 Ma (using the plate model of Whittaker et al., 2013) with the location of the interpreted exhumed continental mantle domain along the Australian-Antarctic ocean-continent transition (green region; after McCarthy et al., 2020). Panels (c) and (d) interpreted multichannel seismic reflection profiles crossing ODP Site 1168 (for the location, see panel b; for details, see the legend). (c) The inset panels show the uninterpreted (Exon et al., 2001b) and interpreted seismic section crossing ODP Site 1168 with tied lithological units. Also shown are the pre-Eocene-Oligocene transition sediment stratigraphy after Sauermilch et al. (2019a) and Hill et al. (1997), and the interpreted continental mantle exhumation following McCarthy et al. (2020). Panel (d) shows the legend of the sedimentary units (Exon et al., 2001b).

depth of $2463.3 \mathrm{~m}$; Fig. 1) reached a total depth of $883.5 \mathrm{~m}$ below the seafloor (mb.s.f.) with a recovery of $98 \%$. The drill site is located within a small, filled sedimentary basin embedded by two basement highs $(\sim 25 \mathrm{~km}$ length; Fig. 1c). The upper Eocene-Miocene sedimentary record has a clear palaeomagnetic signal, from which magnetochrons can be defined by connecting palaeomagnetic re- versals to biostratigraphic events from planktic foraminifera, dinocysts and calcareous nannofossils (Pfuhl and McCave, 2003; Sluijs et al., 2003; Stickley et al., 2004b; Pross et al., 2012; Houben et al., 2019). Here, we recalibrated all of the bio- and magnetostratigraphic datums from Stickley et al. (2004) to the Geologic Time Scale 2012 (GTS2012) (Gradstein et al., 2012), using the latest information from 
the Nannotax and Microtax web catalogues (Young et al., 2017) (Fig. 2 and Table S1 in the Supplement). The Shipboard Scientific Party (Exon et al., 2001a, b) distinguished four lithologic units in the studied interval between 876 and $340 \mathrm{~m}$ b.s.f. (units II to V). Unit V consists of black organic-rich siltstones and claystone of late Eocene age until 762 mb.s.f., overlain by Unit IV (748.6-762 mb.s.f.) which consists of $13.4 \mathrm{~m}$ of dark-grey glauconitic, quartzose sandstone and clayey organic-rich siltstone. Unit III (660-748.6 m b.s.f.) is composed of olive-grey nannofossilbearing organic clayey siltstone. Unit II (340-660 m b.s.f.) is dominated by nannofossil chalks and claystones of varying silt content of Oligocene-early Miocene age. In general, the sediment colour becomes progressively lighter up-section, with increasing calcium carbonate and declining organic carbon content (Fig. 2). Calcium carbonate $\left(\mathrm{CaCO}_{3}\right)$ is low $(<15 \mathrm{wt} \%)$ in Unit $\mathrm{V}$ and highly variable (0 wt \%-40 wt \%) in Unit IV. $\mathrm{CaCO}_{3}$ increases stepwise in units III and II, from $\sim 700$ to $550 \mathrm{~m}$ b.s.f. $(\sim 10 \mathrm{wt} \%-40 \mathrm{wt} \%)$ and from 450 to $\sim 370 \mathrm{~m}$ b.s.f. $(\sim 20 \mathrm{wt} \%-50 \mathrm{wt} \%)$ respectively (Exon et al., 2001b). The total organic carbon (TOC) content is high, 5 wt $\%$, at the bottom of the record and decreases until Unit IV ( $\sim 750 \mathrm{~m}$ b.s.f.). TOC is lower, $<1 \mathrm{wt} \%$, for the interval above $700 \mathrm{~m}$ b.s.f. (units III-II). The average sedimentation rate is calculated as $\sim 6 \mathrm{~cm} \mathrm{kyr}^{-1}$ for the late Eocene, declining to $\sim 3 \mathrm{~cm} \mathrm{kyr}^{-1}$ in the Oligocene and further to $\sim 2 \mathrm{~cm} \mathrm{kyr}^{-1}$ in the early Miocene (Exon et al., 2001b).

\subsection{Palaeolatitude and palaeobathymetry}

Palaeolatitudes for the western Tasmanian margin between 37 and $20 \mathrm{Ma}$ changed from 63 to $55^{\circ} \mathrm{S}$ (van Hinsbergen et al., 2015; Matthews et al., 2016), which is still substantially further south than its modern latitude $\left(42.5^{\circ} \mathrm{S}\right)$. This is due to the progressive opening of the AAG since the late Eocene, which caused a northward movement of Australia (with Tasmania) (Cande and Stock, 2004). The same tectonic widening caused deepening of the Tasmanian continental flanks throughout the Eocene-Oligocene. A recent study by Hochmuth et al. (2020) suggested deepening of the site from inner-neritic to bathyal depths from a palaeodepth of about $700 \mathrm{~m}$ at $29 \mathrm{Ma}$ to a depth of $1500 \mathrm{~m}$ by $21 \mathrm{Ma}$.

\section{Methods}

\subsection{Seismic stratigraphy}

We present seismo-stratigraphic interpretations of two multichannel seismic reflection profiles crossing (line SO36-47) and closely passing (line N417) Site 1168 (Fig. 1c, d). We follow the seismic interpretation of Sauermilch et al. (2019a) and Hill et al. (1997) for the sedimentary units and continental crust, and the exhumed subcontinental mantle part is our own (following the characteristics of McCarthy et al., 2020). Key reflections are linked to lithological units, largely fol- lowing interpretations by Sauermilch et al. (2019a) and the Shipboard Scientific Party (Exon et al., 2001b). We used the time-depth relationship derived from downhole sonic pwave velocities measured at Site 1168 (Exon et al., 2001b) for the core-seismic correlation. This method of velocity measurements is most accurate for seismic integration, particularly for calcareous-rich sediments (Sauermilch et al., 2019b).

ODP Site 1168 is located within an enclosed sedimentary basin, surrounded by now buried bathymetric highs (Fig. 1c). Characteristic seismic features, amplitude and internal reflection patterns can be used to follow key reflections and sedimentary units across this embedded basin. However, some uncertainties remain, as the basement highs disrupt the continuity of the reflection pattern. In order to calculate the regional thickness extensions of the sedimentary units in metres, we use interval velocities from downhole sonic measurements at Site 1168. We interpreted the exhumation of subcontinental mantle material offshore of western Tasmania, along its ocean-continent transition zone (OCT; Fig. 1). The interpretation of the mantle domain followed the analytical scheme of Gillard et al. (2015) and McCarthy et al. (2020), who investigated exhumed mantle domains of the offshore central southern Australian and conjugate East Antarctic margins (Seamount B, east of Adélie Rift Block) respectively.

\subsection{Palynological processing and analysis}

We studied 123 samples for palynological content: 84 were samples that were revisited and recounted from the previously studied palynological record by Brinkhuis et al. (2003), and 39 were additional samples processed to increase the resolution. The processing of sedimentary samples for palynological analysis followed standard procedures at the Laboratory of Palaeobotany and Palynology, Utrecht University (e.g. Brinkhuis et al., 2003; Bijl et al., 2018). Dried sediment samples were crushed and weighed (on average $10 \mathrm{~g}$, standard deviation, $\mathrm{SD}$, of $<1 \mathrm{~g}$ ) before they were digested with $30 \%$ cold hydrochloric acid $(\mathrm{HCl})$ and $38 \%$ cold hydrofluoric acid (HF) for carbonate and silicate removal respectively. The remaining palynological residues were sieved on a $10 \mu \mathrm{m}$ nylon mesh, using an ultrasonic bath to disintegrate agglutinated organic particles. No oxidation or alkali agents were used. The palynological residues were mounted on glass slides using glycerine jelly, sealed with nail varnish and counted (under $400 \times$ magnification) using a Leica DM2500 LED transmitted light optical microscope. When possible, at least 200 dinocyst specimens were counted (Mertens et al., 2009). Slides containing less than 50 dinocyst specimens were excluded from further analysis. 


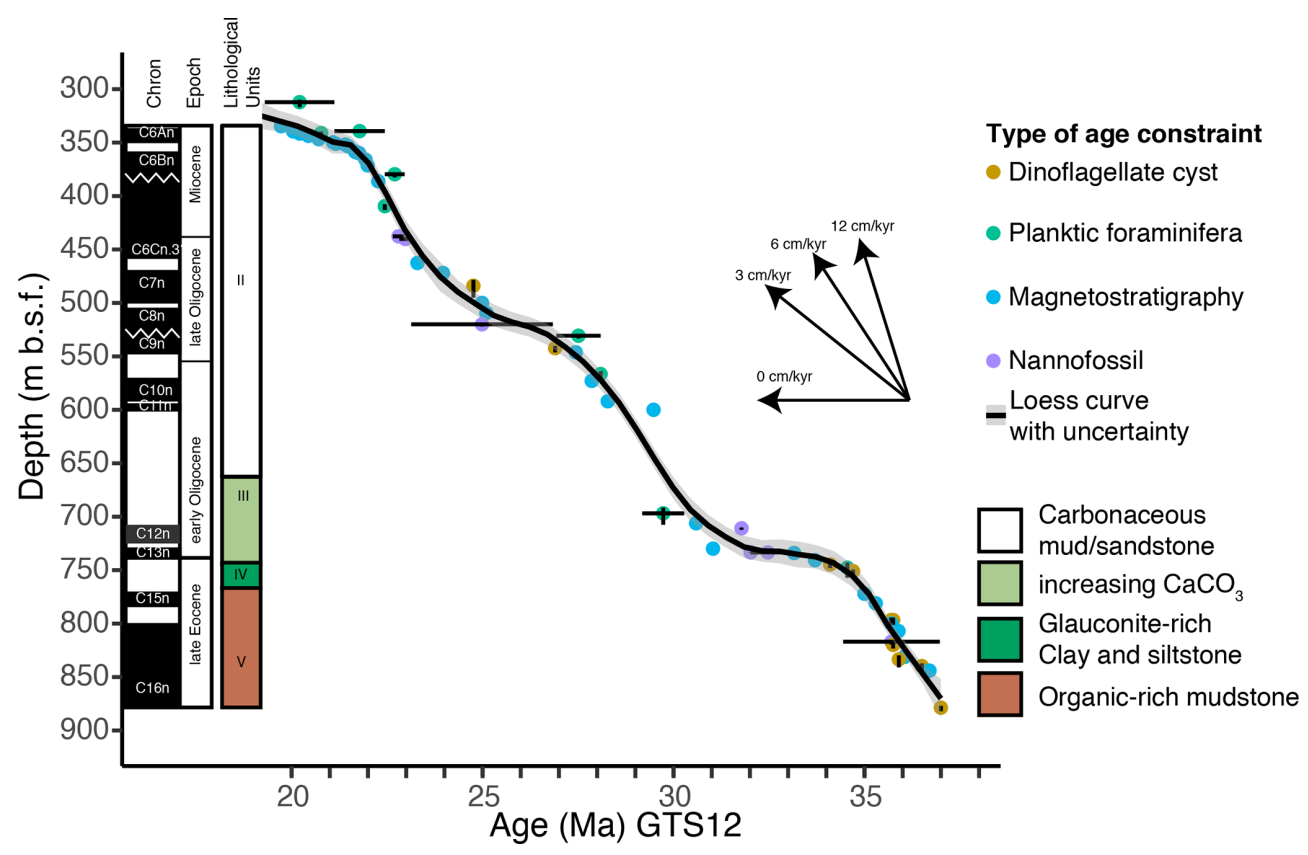

Figure 2. Age-depth model of ODP Site 1168, based on magneto- and biostratigraphy (calcareous nannofossils, planktic foraminifera, diatoms and dinocysts) after Stickley et al. (2004b), here recalibrated to GTS2012 of Gradstein et al. (2012) (Table S1 in the Supplement). A smoothed line is drawn through the age constraints using the loess smoothing method with a span of 0.1 . Lithological units are indicated to the right of the palaeomagnetic chrons and the indication of epochs (Exon et al., 2001b). The arrows indicate the sedimentation rate.

\subsection{Marine palynomorph taxonomy and distribution patterns}

We provide detailed counts of dinocysts and other aquatic palynomorphs (acritarchs and prasinophyte algae) (Table S2 in the Supplement). Dinocyst taxonomy as cited in Williams et al. (2017) is followed. Acritarch and prasinophyte taxonomy follows that of Hannah (1998, 2006), Prebble et al. (2006) and Hartman et al. (2018a). We also included a broad count of terrestrial palynomorphs in order to calculate the relative abundances between terrestrial and marine palynomorphs. Detailed analyses of terrestrial palynomorphs and terrestrial palaeoenvironmental evolution at Site 1168 is the focus of another paper (Amoo et al., 2021).

\subsubsection{Dinocyst ecological preferences}

The present-day distribution of dinocysts (Fig. 3) depends mostly on surface water temperature but also on nutrient availability, salinity, water depth, bottom-water oxygen, primary productivity and sea-ice cover (e.g. Dale, 1996; Prebble et al., 2013; Zonneveld et al., 2013; Marret et al., 2020). In order to use dinocyst assemblages as palaeoceanographic proxies, we assume that the habitat affinities and trophic strategy of modern dinoflagellate species have remained similar through time; therefore, we utilise the modern relationship between dinocysts and overlying water properties as a model for the "deep-time" ecological niches (Sluijs et al., 2005; Prebble et al., 2013; Sangiorgi et al., 2018). Palaeoe- cological preferences of extinct species are uncertain. To tackle this problem, the ecological affinity of extinct dinocyst taxa was reconstructed across well-defined climatic transitions (Brinkhuis, 1994; Houben et al., 2013; Egger et al., 2018), using the co-occurrence of extinct species with those for which the ecological information is still available, e.g. modern species (e.g. Schreck and Matthiessen, 2013), or in comparison to other palaeoceanographic proxies for temperature, runoff/freshwater input and nutrient conditions (Bijl et al., 2011; De Schepper et al., 2011; Frieling and Sluijs, 2018).

In this paper, we apply this principle to divide dinocyst taxa into eco-groups (Table 1), based on the context of the Southern Ocean. We utilise the notion that protoperidinioid cysts and peridinioid dinocysts in general (e.g. Protoperidinium cpx., Deflandrea spp. and Svalbardella spp.) are predominantly produced by heterotrophic dinoflagellates and, thus, prefer a habitat with nutrient-rich, productive surface waters, whereas gonyaulacoid dinocysts principally reflect autotrophic/phototrophic dinoflagellates and distribute themselves mostly according to other surface water parameters (e.g. Pross and Brinkhuis, 2005; Sluijs et al., 2005). Cysts derived from heterotrophic dinoflagellates, notably the protoperidinioids, are generally more sensitive to oxic bottom conditions than autotrophic dinoflagellates, which may, to an unknown degree, represent bias in the interpretation of relative abundance data in dinocyst assemblages (Zonneveld et al., 2010). Some dinocyst taxa are known to have strong tem- 


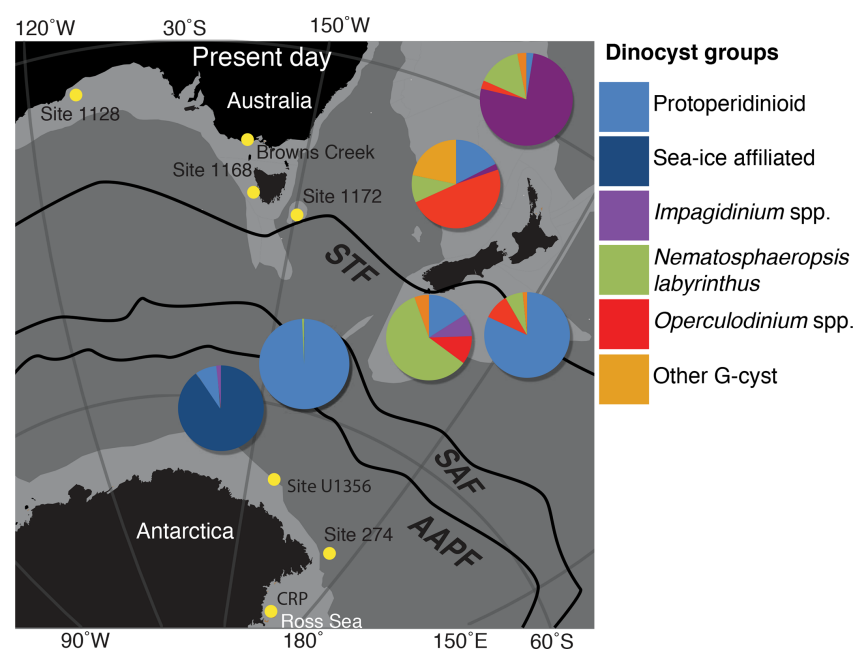

Figure 3. The present-day distribution of dinoflagellate cyst assemblages in the southwest Pacific sector of the Southern Ocean, derived from surface sample data generated by Prebble et al. (2013) and displayed in Sangiorgi et al. (2018). The black lines illustrate the location of oceanic fronts (Orsi et al., 1995), and yellow dots mark the present-day locations of the drill sites studied (ODP Site 1168) and discussed in this paper (IODP Site U1356, ODP Site 1172 and 1128, DSDP Site 269 and 274, Cape Roberts Project - CRP, and Browns Creek). STF is the subtropical front, SAF is the subantarctic front and AAPF is the Antarctic polar front. Land masses are indicated in black, and the continental lithosphere is shown in light grey in the location map generated by GPlates freeware (http://www.gplates.org, last access: 13 June 2016), based on the global plates geodynamic motion model from Müller et al. (2018).

perature preferences. Typical cold-water indicators are Svalbardella spp. (van Simaeys et al., 2005) and Gelatia inflata (e.g. Egger et al., 2018), whereas Hystrichokolpoma rigaudiae (Louwye et al., 2008) and Lingulodinium machaerophorum (e.g. De Schepper et al., 2011) are taxa indicative of warm water. We also use the neritic to oceanic classification scheme of dinocyst taxa by Pross and Brinkhuis (2005) in order to deduce proximity to the shoreline. Further, we discuss the changes in surface-ocean current influence by analysing the relative abundance of Antarctic-endemic, cosmopolitan and low-latitude taxa (Sluijs et al., 2005; Bijl et al., 2011). These papers show that surface-ocean currents derived from the waters surrounding Antarctica are dominated by Antarctic-endemic dinocysts, whereas mid-/lowlatitude-derived currents such as the East Antarctic Current and proto-Leeuwin Current are sources of cosmopolitan and low-latitude taxa.

Finally, we track Southern Ocean frontal systems' movements using the environmental associations of modern dinocysts by Prebble et al. (2013) as a model. Today, a pronounced latitudinal separation of dinocyst assemblages across the Southern Ocean exists (Prebble et al., 2013) (Fig. 3). Surface samples from the Antarctic margin, south of the subantarctic front (SAF), are dominated by the peridinioid cysts Selenopemphix antarctica with a minor abundance of Brigantedinium spp. (Prebble et al., 2013), whereas the dinocyst assemblage in the surface sample at Site 1168 shows abundant Gonyaulacoid cysts of the genera Impagidinium, Nematosphaeropsis, Spiniferites and minor occurrence of the peridinioid cyst Brigantedinium. The latter dominates the polar frontal zone, where mixing and upwelling of nutrient-rich waters and strong seasonality in sea-ice cover exists. Nematosphaeropsis, Operculodinium and Impagidinium prevail in surface waters with mean annual temperatures of $8-17^{\circ} \mathrm{C}$ (Prebble et al., 2013). Abundant $\mathrm{Ne}$ matosphaeropsis has been described as an indicator of the region south of the STF, in the subantarctic zone (Prebble et al., 2013). The highest abundances of the cosmopolitan Operculodinium centrocarpum sensu Wall and Dale (1966) are found in samples north of the STF. Impagidinium spp. is abundant under (relatively warm) oligotrophic, oceanic, conditions (Zonneveld et al., 2013). I. aculeatum is most abundant south of the STF, and I. paradoxum is slightly more abundant north of the STF (Prebble et al., 2013). An exception is I. pallidum, which is abundant in both polar areas in the modern ocean (Zonneveld et al., 2013; Marret et al., 2020) but is also recorded at temperate sea surface temperatures (SSTs) during the Neogene (De Schepper et al., 2011). Therefore, we interpret the palaeoecological significance of I. pallidum in the past with caution (De Schepper et al., 2011), and place this species in the Impagidinium group. Members of the long-ranging cosmopolitan Spiniferites spp. appear most abundantly north of the STF. S. ramosus is most common, and in more shore-proximal settings, $S$. mirabilis is today most common between 30 and $40^{\circ} \mathrm{S}$ and with SSTs $>15^{\circ} \mathrm{C}$ (Zonneveld et al., 2013).

\subsubsection{Acritarchs and organic remains of prasinophyte algae}

Acritarchs represent "acid resistant organic walled microfossils of unknow affinity" (Evitt, 1963) and likely represent organic remains of polyphyletic origin, including prasinophyte algae. As of 2021, the latter group has received more attention, and some life cycle stages are indeed composed of preservable organic matter (Parke et al., 1978; Mudie et al., 2021). These may be single-celled and/or multicellular, colonial stages. Examples include the multicellular Botryococcus and Pediastrum, and the unicellular Tasmanites and Pterospermella spp. Although there are large uncertainties regarding the biological and ecological affinity of acritarchs and prasinophytes, they are often considered as potentially opportunistic species and often co-occur with indications of increased freshwater input and increased stratification (Mudie, 1992; Hannah, 2006; Prebble et al., 2006; De Schepper and Head, 2014). At the Antarctic margin, acritarchs such as Leiosphaeridia spp. have been associated with glacial retreat and freshwater discharge (Hannah, 2006; Warny et al., 2006; 
Table 1. Dinocyst assemblage groups and their ecological and frontal system affinity.

\begin{tabular}{|c|c|c|}
\hline Complex & Dinocyst taxa & Ecological affinity \\
\hline Homotryblium cpx. & $\begin{array}{l}\text { Homotryblium } \mathrm{spp} . \\
\text { Eocladopyxis } \mathrm{spp} . \\
\text { Heteraulacacysta } \mathrm{spp} . \\
\text { Polysphaeridium } \mathrm{spp} .\end{array}$ & $\begin{array}{l}\text { Inner-neritic/restricted marine-lagoonal setting } \\
\text { (Sluijs et al., 2005; Frieling and Sluijs, 2018) }\end{array}$ \\
\hline Glaphyrocysta cpx. & $\begin{array}{l}\text { Glaphyrocysta spp. } \\
\text { Areoligera semicirculata }\end{array}$ & $\begin{array}{l}\text { Inner-neritic, high-energy settings (Stover et al., 1996; Sluijs et al., } \\
\text { 2005) }\end{array}$ \\
\hline Cleistosphaeridium срх. & $\begin{array}{l}\text { Cleistosphaeridium spp. } \\
\text { Dapsilidinium } \mathrm{spp} . \\
\text { Enneadocysta } \mathrm{spp} .\end{array}$ & Inner-neritic, relatively marginal setting (Brinkhuis, 1994) \\
\hline Cribroperidinioideae & $\begin{array}{l}\text { Apteodinium australiense } \\
\text { Cooksonidium capricornum } \\
\text { Cordosphaeridium cantharellus } \\
\text { C. fibrospinosum } \\
\text { C. minimum } \\
\text { Thalassiphora pelagica }\end{array}$ & Mid-shelf and neritic environments (Brinkhuis, 1994) \\
\hline Lingulodinium cpx. & L. machaerophorum & $\begin{array}{l}\text { Inner- to outer-neritic, warm, seasonally stratified waters, medium- } \\
\text { high nutrients (Sluijs et al., 2005; Zonneveld et al., 2013) }\end{array}$ \\
\hline Pyxidinopsis cpx. & $\begin{array}{l}\text { Batiacasphaera spp. } \\
\text { Cerebrocysta } \text { spp. } \\
\text { Corrudinium spp. } \\
\text { Pyxidinopsis spp. }\end{array}$ & $\begin{array}{l}\text { Outer-neritic setting } \\
\text { (Brinkhuis, 1994; Sluijs et al., 2005) }\end{array}$ \\
\hline Reticulatosphaera & R. actinocoronata & $\begin{array}{l}\text { Outer-neritic setting (Brinkhuis, 1994; Pross and Brinkhuis, 2005; } \\
\text { Sluijs et al., 2005) }\end{array}$ \\
\hline Hystrichokolpoma spp. & & Outer-neritic/oceanic setting (Pross and Brinkhuis, 2005) \\
\hline Spiniferites cpx. & $\begin{array}{l}\text { Spiniferites ramosus } \\
\text { S. mirabilis } \\
\text { Achomosphaera alcicornu } \\
\text { Hafniasphaera septata }\end{array}$ & $\begin{array}{l}\text { Cosmopolitan environment (Brinkhuis, 1994; Zonneveld et al., } \\
\text { 2013) }\end{array}$ \\
\hline Operculodinium spp. & $\begin{array}{l}\text { Operculodinium centrocarpum } \\
\text { O. piaseckii } \\
\text { O. janduchenei }\end{array}$ & $\begin{array}{l}\text { Cosmopolitan/oceanic environment } \\
\text { Abundant north of STF (Brinkhuis, 1994; Prebble et al., 2013) }\end{array}$ \\
\hline Impagidinium spp. & $\begin{array}{l}\text { Impagidinium aculeatum } \\
\text { I. dispertitum } \\
\text { I. maculatum } \\
\text { I. sphaericum } \\
\text { I. paradoxum } \\
\text { I. patulum } \\
\text { I. pallidum* }\end{array}$ & $\begin{array}{l}\text { Oligotrophic oceanic environment (Wall et al., 1977; Pross and } \\
\text { Brinkhuis, 2005; Zonneveld et al., 2013) } \\
\text { * Abundant in both polar areas of the modern ocean (Zonneveld et } \\
\text { al., 2013; Marret et al., 2019) but also recorded in association with } \\
\text { temperate SSTs in the Neogene (De Schepper et al., 2011) }\end{array}$ \\
\hline Nematosphaeropsis labyrinthus & & Oceanic/subantarctic zone (Crouch et al., 2010; Prebble et al., 2013) \\
\hline Gelatia inflata & & $\begin{array}{l}\text { Cold-water setting (Brinkhuis and Biffi, 1993; Guerstein et al., } \\
\text { 2008) }\end{array}$ \\
\hline Deflandrea spp. & Deflandrea spp. & $\begin{array}{l}\text { Heterotrophic, neritic to oceanic setting (Röhl et al., 2004; Sluijs et } \\
\text { al., 2005) }\end{array}$ \\
\hline Protoperidinioid cpx. & $\begin{array}{l}\text { Brigantedinium spp. } \\
\text { Lejeunecysta spp. } \\
\text { Selenopemphix } \text { spp. } \\
\text { Protoperidinium spp. }\end{array}$ & $\begin{array}{l}\text { Nutrient-rich cold waters, related to inner-neritic environments } \\
\text { (Harland and Pudsey, 1999; Sluijs et al., 2003; Zonneveld et al., } \\
\text { 2013) }\end{array}$ \\
\hline Svalbardella spp. & Svalbardella cooksoniae & Cold water tolerant (van Simaeys et al., 2005) \\
\hline
\end{tabular}


2016) and are still present in modern samples (Hartman et al., 2018a). However, abundant skolochorate acritarchs in the Oligocene-Miocene at the Wilkes Land coast are associated with incursions of warm water (Bijl et al., 2018). Brinkhuis et al. (2003) also reported samples with a massive influx of small skolochorate acritarchs of unknown affinity around Tasmania at Site 1168 and Site 1172, in addition to the remains of prasinophyte algae. Prasinophyte algae, such as $C y$ matiosphaera spp. and Tasmanites spp., accumulate in relatively near-shore marine to brackish nutrient-rich environments (Mudie et al., 2021).

\section{Results}

\subsection{Seismic stratigraphy}

The lithological boundaries from ODP Site 1168 are tied to the crossing seismic reflection profile (Fig. 1c) using the time-depth relationship from downhole sonic velocities (Exon et al., 2001a, b). The drilled lithological units V and III-I are clearly visible in the seismic lines, whereas the very thin $(13.4 \mathrm{~m})$ Unit IV is only detectable as a strong reflection pattern (Fig. 1c). An additional key unconformity underlies the drilled sections, dated to the Palaeocene, extrapolated from industry well site Cape Sorell 1 (Boreham et al., 2002) (Fig. 1c). Here, we focus on the sedimentary units V-II, deposited between the late Eocene and early Miocene.

\section{Unit V-IV}

Unit $\mathrm{V}$ reaches a maximum thickness of about $0.5 \mathrm{~s}$ TWT (two-way travel time) or $\sim 400-500 \mathrm{~m}$. In the embedded basin, the thickest part of Unit V is located towards the land. The internal reflections in the upper part of this unit are chaotic, with varying amplitudes and characteristic hummocky structures. Internal reflections and the top boundary thin out and onlap onto both basement highs, southwest and northeast (Fig. 1c). However, the top boundary reflection slightly overlaps the basement high oceanward in the WNWESE direction (Fig. 1d). As the lithological Unit IV is very thin and barely detectable in the seismic data, it is likely that this overlapping section is Unit IV.

The seismic characteristics of the upper section of Unit $\mathrm{V}$ are significantly different on each side of the Tasmanian Fracture Zone (TFZ) and the connected basement highs. The deposition east of the TFZ, around Site 1168, shows chaotic, hummocky features and reworking. Particularly the hummocky reflections have been previously interpreted as deltaic influence (Exon et al., 2001a, b). West of the TFZ, the deposition of the late Eocene material is more homogenous and undisturbed along the upper slope (Fig. 1d). Further offshore along the lower continental slope to abyssal plain, this sedimentary unit has been slightly reworked. This structure shows onlapping reflections onto the slope and is likely part of the contourite drift system observed along the Aus- tralian and Antarctic margins that formed due to strengthening clockwise currents in the AAG (Sauermilch et al., 2019a).

\section{Unit III}

The overlying Unit III, dated to the early Oligocene, is thinner (maximum thickness $\sim 0.3 \mathrm{~s}$ TWT in the embedded basin) with internal reflections of weaker amplitudes. Towards the landward basement high, sediment waves are observed that continue to be present and intensify in the overlying late Oligocene-early Miocene unit (Unit II; Fig. 1c). Unit III becomes significantly thicker towards the foot of the continental slope with internal reflections onlapping onto the slope (Fig. 1d).

\section{Unit II}

Unit II is $\sim 0.5 \mathrm{~s}$ TWT thick and its top boundary reflection onlaps onto the peak of both basement highs (Fig. 1c). A high-amplitude internal reflection within Unit II can be correlated to the Oligocene-Miocene transition (Fig. 1c, insets). The upper section of Unit II (early Miocene; $\sim 0.3 \mathrm{~s}$ TWT thick) contains high-amplitude, relatively undisturbed and parallel internal reflections. At each end of the basin, the unit's internal and top boundary truncate to a prominent unconformity, which has been correlated to the mid-late Miocene transition (Fig. 1c).

\section{Ocean-continent transition}

The most oceanward (SW) section of the seismic line (Fig. 1c) shows features characteristic of subcontinental mantle exhumation. A high-amplitude, continental dipping reflection is detected at $\sim 10 \mathrm{~s}$ TWT depth, which rises up to about $9 \mathrm{~s}$ TWT and disappears (Fig. 1c; shot points, SP, 2500-3200). This sharp rising feature is interpreted as the Moho boundary and is characteristic of regions with exhumed subcontinental mantle along the ocean-continent transition (OCT; Gillard et al., 2015; McCarthy et al., 2020). The continental basement and pre-/syn-rift sediments contain closely spaced fault structures, indicating major deformation in the region during mantle exhumation. The imaged domain of exhumed mantle in the seismic line is about $30 \mathrm{~km}$ wide; however, it likely continues oceanward, beyond the extension of the seismic line.

\subsection{Palynological assemblages}

We record a fair coupling between changes in lithology and changes in the three major palynomorph groups: dinocysts, acritarchs and terrestrial palynomorphs (Fig. 4). The terrestrial palynomorphs are dominant in the upper Eocene-lower Oligocene part (units V-III) of the record, which also has the highest TOC levels. In the middle of lithological Unit III, below $700 \mathrm{~m}$ b.s.f. (30.5 Ma), the high relative abundance 

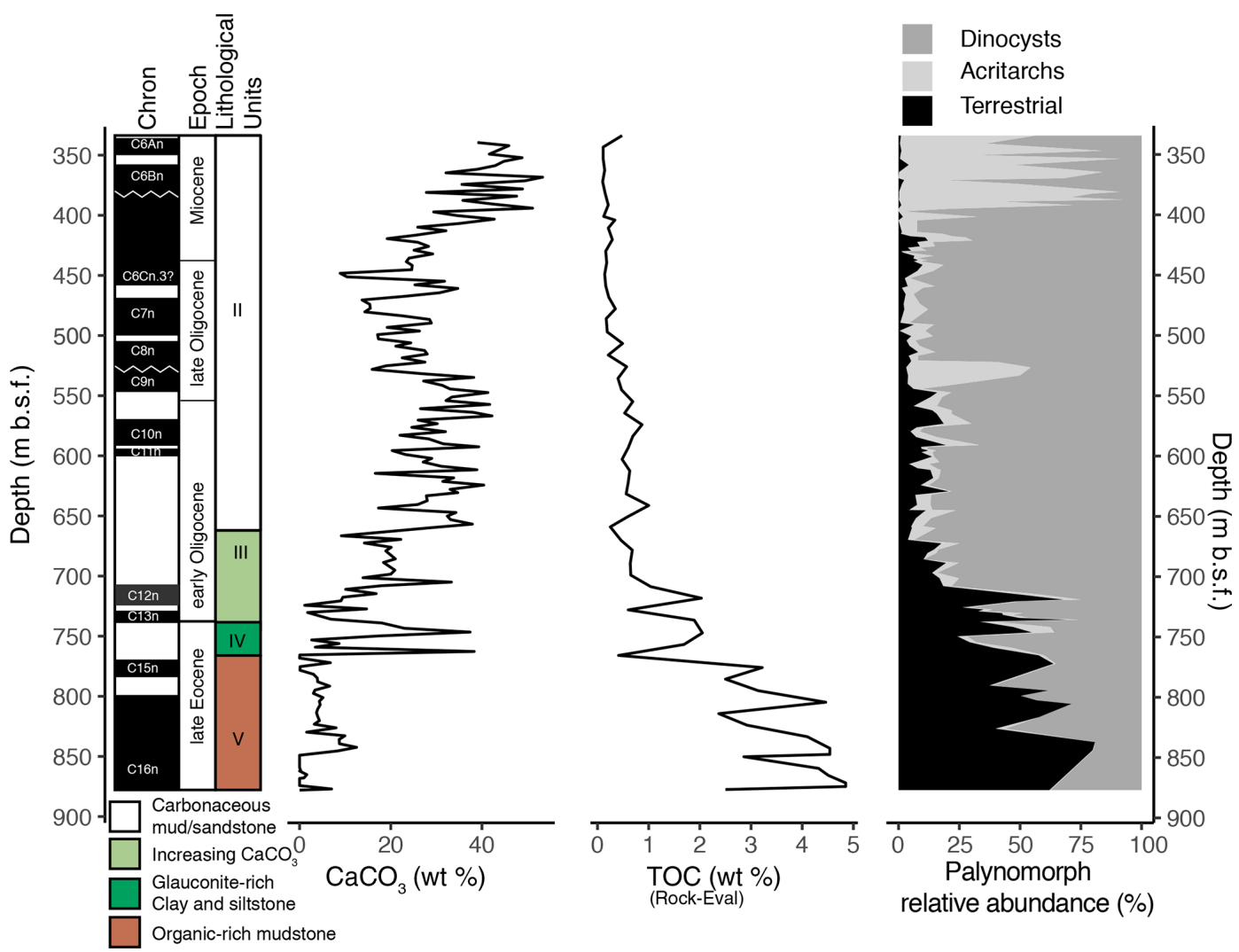

Figure 4. Stacked relative abundance of the three major palynomorph groupings (terrestrial palynomorphs, acritarchs and dinocysts), plotted against depth (m b.s.f.), next to the magnetostratigraphic framework (Gradstein et al., 2012), lithological units, and shipboard total organic carbon (TOC, wt \%) and calcium carbonate $\left(\mathrm{CaCO}_{3}\right.$, wt \%) data (Exon et al., 2001b).

of terrestrial palynomorphs rapidly decreases to $5 \%-15 \%$, concomitant with a decrease in TOC, and remains low in the overlying nannofossil chalks and silty claystones (Unit II). In the Oligocene, from 700 to $400 \mathrm{~m}$ b.s.f. (30.5-22.4 Ma), dinocysts are the most abundant palynomorph group and comprise up to $88 \%$ of all palynomorphs. In the Miocene, acritarchs dominate the assemblages, reaching up to $90 \%$ of the total palynomorph assemblage. Acritarchs reach the highest relative and absolute abundances at $540-520 \mathrm{~m}$ b.s.f. and above $400 \mathrm{~m}$ b.s.f. The second peak in the lower Miocene is synchronous with increased amounts of calcium carbonate (40 wt \%).

\subsubsection{Dinocyst assemblages}

From the 123 samples counted, 106 samples yield abundant and well-preserved dinocysts (Fig. 5). Identification of dinocysts on a species level was possible in most cases; however, some dinocysts were only categorised on a genus level when distinctive features were lacking. The quantitative requirement of counting to a minimum of 200 dinocyst was met for most of the samples, except for those from the upper Eocene, where terrestrial palynomorphs dominate the record, and from the lower Miocene, where acritarchs dominate the palynomorph assemblages (Table S2 in the Supplement).

Dinocyst assemblages are dominated by the Gonyaulacoid (autotrophic) taxa Spiniferites spp. (30\%-90\%), with the common $(5 \%-25 \%)$ and consistent occurrence of Operculodinium spp., Cleistosphaeridium spp. and Hystrichokolpoma spp. Dinocysts of the family Cribroperidinioideae were sporadically present to common $(10 \%-$ $40 \%)$. Other dinocysts taxa present $(0 \%-10 \%)$ throughout were Glaphyrocysta cpx., Lingulodinium spp., Pyxidinopsis cpx., Reticulatosphaera spp., Gelatia inflata and the Goniodomideae of the genus Homotryblium. Among the heterotrophic dinocysts, Deflandrea spp. and the Protoperidinioid cpx. (including Brigantedinium spp., Protoperidinium spp., Lejeunecysta spp. and Selenopemphix spp.) were common (10\%-20\%) prior to $30.5 \mathrm{Ma}$ (phase 1) and remained present (0\%-10\%) throughout the record. Svalbardella spp. is present in a short interval between 26.8 and $27.5 \mathrm{Ma}$ (Chron C9n). The dinocyst assemblages show increasingly consistent occurrences of more outer-neritic to open-oceanic and cosmopolitan taxa such as Cleistosphaeridium, Hystrichokolpoma spp., Reticulatosphaera spp., and increasingly more abundant Spiniferites spp., Operculodinium spp., 


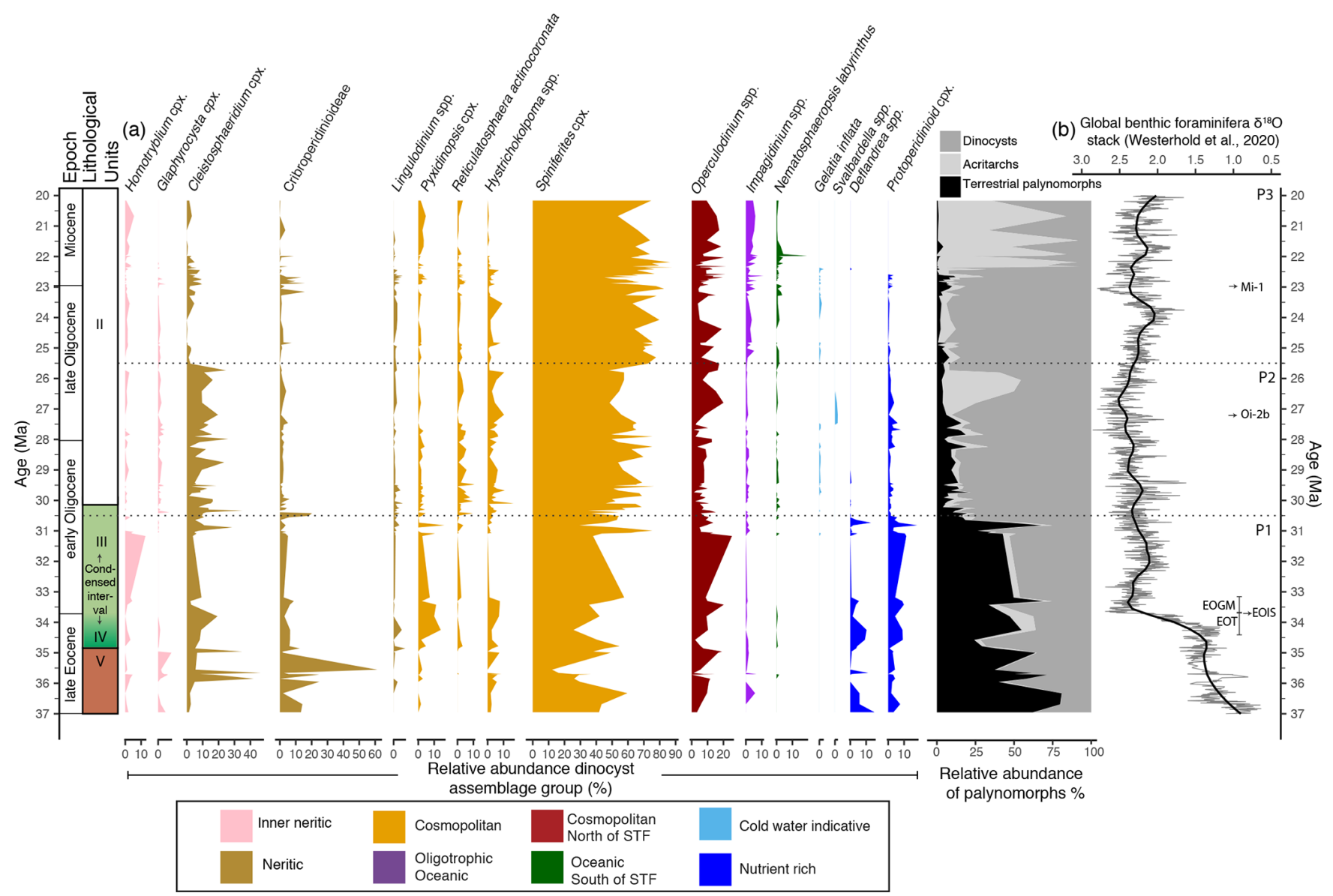

Figure 5. (a) Relative abundance (\%) of selected dinocyst taxa and/or groups (Table 1), ordered from their known occurrence in inshore (left) to offshore (right) environments, with heterotrophic taxa (light and dark blue) to the right. Dinocyst taxa have been assigned to an ecological group (see legend), based on the context of this study, consistent with interpretations from Röhl et al. (2004) and Frieling and Sluijs. (2018). The relative abundance of terrestrial palynomorphs, acritarchs and dinocysts with respect to the total palynomorph counts is shown in greyscale. (b) Global benthic foraminiferal $\delta^{18} \mathrm{O}$ stack record by Westerhold et al. (2020). The thick black line represents the loess smoothing curve with a span of 0.1. Selected isotopic events are marked, following Hutchinson et al. (2021): EOT is the Eocene-Oligocene transition, EOGM is the earliest Oligocene glacial maximum, EOIS is the earliest Oligocene oxygen isotope step, Oi-2b is the Oligocene glaciation/isotopic event $2 \mathrm{~b}$ and Mi-1 is the Miocene glaciation/isotopic event 1 . The stippled black lines at 30.5 and $25.5 \mathrm{Ma}$ distinguish the three phases/time intervals (P1, P2 and P3) discussed in Sect. 5.1.

Impagidinium spp. and Nematosphaeropsis labyrinthus. At $25.5 \mathrm{Ma}$ (phase 3), Cleistosphaeridium cpx. rapidly decreases, Spiniferites cpx. becomes highly dominant, and Impagidinium spp., with I. paradoxum as the most common species, becomes increasingly more abundant. A pronounced increase in the abundance of Apteodinium australiense (Cribroperidinioideae) occurs at the OligoceneMiocene boundary interval $(\sim 23.1-22.9 \mathrm{Ma})$. A peak in the abundance of Nematosphaeropsis labyrinthus occurs around $22 \mathrm{Ma}$. Simultaneously, Hystrichokolpoma rigaudiae and Lingulodinium machaerophorum decrease to their lowest abundance in the study record. Increasing the sample resolution and the number of dinocysts counted per sample in this study led similar dinocyst assemblages being found to those presented in the initial report by Brinkhuis et al. (2003).

\subsubsection{Acritarchs and other palynomorphs}

Acritarch assemblages are dominated by skolochorate forms. We informally name occasionally abundant unidentified small $(10 \mu \mathrm{m})$ skolochorate acritarchs with various spine lengths as Acritarch sp. 1 (long spines) and Acritarch sp. 2 (short spines) (Plate S1 in the Supplement). The abundance of acritarchs does not correlate to that of reworked dinocysts, which argues for in situ production. We record a large peak in Acritarch sp. 2 around 25.8-26.8 Ma. Acritarch sp. 1 (long spines) becomes the dominant (40\%-90\% of total marine palynomorphs) palynomorph in the early Miocene part of the record (22.3-20 Ma). Smooth-walled transparent spheres are recorded as Leiosphaeridia. Members of Leiosphaeridia spp. generally appear in low abundance $(<5 \%)$ from $35 \mathrm{Ma}$ onwards. Transparent spheres with a perforated wall structure 
are informally named Acritarch sp. $3(15-20 \mu \mathrm{m}$; Plate S1 in the Supplement). Acritarch sp. 3 first appears after $33.5 \mathrm{Ma}$ and sporadically appears in low abundance $(0 \%-6 \%)$ until 22.6 Ma. Prasinophyte algae Cymatiosphaera spp. is sporadically present in very low numbers $(<3 \%$ of total marine palynomorphs) in the Oligocene. Tasmanites spp. is only present in very low numbers between 35 and $30.6 \mathrm{Ma}$ (Table S2 in the Supplement).

\section{Discussion}

\subsection{Local depositional environment and palaeoenvironmental changes}

Based on changes in the relative abundance of dinocyst assemblage groups, acritarchs and terrestrial palynomorphs (Fig. 5), we divide the record into three phases (P1-P3) of regional palaeoenvironmental change, independent of the lithological units, and compare these to the seismic and lithological investigations at Site 1168: (1) 37-30.5 Ma - transition from mid-shelf to outer-neritic conditions; (2) $30.5-25.5 \mathrm{Ma}$ - outer-neritic conditions with transport of detrital material from the shelf; and (3) $25.5-20 \mathrm{Ma}$ - transition from outerneritic to more oligotrophic, oceanic conditions and frontal system development.

\subsubsection{Late Eocene-early Oligocene (P1: $37-30.5 \mathrm{Ma})$}

Dinocyst assemblages with abundant Spiniferites spp. suggest a shallow mid-shelf setting on the western Tasmanian continental margin at this time, although with strong input from shallow depositional settings (interpreted from the abundance of terrestrial palynomorphs and lagoonal $\mathrm{Ho}$ motryblium cpx.). Heterotrophic Deflandrea spp. and Brigantedinium spp. are common, and terrestrial input (30\%$75 \%$ terrestrial palynomorphs) is high. The combination of these suggests high freshwater runoff from the shore, which increased the nutrient input to the site, favouring primary productivity. The observed seismic hummocky structures in the upper part of Unit $\mathrm{V}$ also reflect transport from shallower parts of the continental shelf.

During the rift to drift transition of Australia and Antarctica, the sedimentary environment along the western Tasmanian margin was likely strongly affected by the activity of the Sorell Fault Zone which later extended to the Tasman Fracture Zone with the onset of seafloor spreading (Fig. 1a, b) (e.g. Miller et al., 2002). This tectonic feature likely acted as a bathymetric barrier for ocean circulation to reach Site 1168 (e.g. Hill and Exon, 2004; Sauermilch et al., 2019a). In addition, recently published petrological and geophysical data directly along the conjugate Antarctic margin revealed that the late rifting stage was affected by the exhumation of subcontinental mantle (Seamount B, east of Adélie Rift Block; McCarthy et al., 2020). Petrological constraints tentatively indicate that melt infiltrated into the subcontinental mantle along the OCT during its rift to drift transition. This likely led to heating of the subcontinental mantle and changing petrological characteristics, increasing the buoyancy of the region. Consequently, this could have led to uplift and/or slower thermal subsidence compared with those of "normal" (mid-ocean ridge basalt) oceanic crust (e.g. Müntener et al., 2010). Seismic data along the western Tasmanian margin indicate a similar mantle exhumation pattern (Fig. 1c). As Seamount B and Site 1168 are directly conjugate, it can be assumed that the mantle uplift could also have affected the western Tasmanian margin, leading to an uplift and/or delayed thermal subsidence of the Tasmanian margin during the time of continental break-up. Organic-rich sediments indicate eutrophic, poorly ventilated bottom conditions, possibly sluggish circulation. This is in line with the palynological and seismic interpretation of a shallow and enclosed graben system.

In the glauconitic interval (Unit IV) that straddles the EOT, lithology and dinocyst assemblages become more variable, probably as a result of the progressive deepening of the continental slope. Unit IV is very thin and only visible as a strong seismic reflection. Therefore, it is difficult to distinguish between upper Unit V and Unit IV in the seismic profiles. However, the boundary reflection is clearly wavy with hummocky features (Fig. 1c, insets), which could be an indicator for winnowing. The early Oligocene section overlying the glauconite layer corresponds to seismic Unit III with sediment waves along the landward basement high (Fig. 1c). These indicate some bottom current activity and increased oxygen delivery, although signs of winnowing have now ceased. As a result, TOC decreases while $\mathrm{CaCO}_{3}$ increases. The return of coastal assemblages and terrestrial palynomorphs around 31 Ma might reflect the Oi-2a glaciation event (Miller et al., 1991; Palike et al., 2006; Galeotti et al., 2016; Westerhold et al., 2020). This caused a lower sea level at these latitudes (Gallagher et al., 2020), which spurred sediment transport from the Australian continental margin. However, the overall decrease in terrestrial palynomorphs, (proto) peridinioid cysts and inner-neritic dinocysts in the glauconite layer does reflect deepening of the Tasmanian continental slope between $\sim 35.5$ and $30.5 \mathrm{Ma}$, consistent with that in nearby Site 1172 (Stickley et al., 2004b) and with final separation between Tasmania and Antarctica (Whittaker et al., 2013).

\subsubsection{Oligocene transitional phase (P2: 30.5-25.5 Ma)}

In this interval, the cosmopolitan dinocysts Spiniferites spp. become more dominant, and species indicative of coastal/lagoonal environments and terrestrial palynomorphs decrease abruptly around $30.5 \mathrm{Ma}$, indicating that the distance to shore has potentially increased, although the site is still at or close to the continental shelf. Throughout the Oligocene, occasional peaks of the neritic groups Cleistosphaeridium cpx. and Cribroperidinioideae indicate varying influx from the inner-neritic shelf, perhaps as a result of sea level changes (Gallagher et al., 2013). The seismic pro- 
files show wavy sediment structures in units III and II along the landward basement high. During the late Oligocene, they intensify and form more prominently in Unit II, which could indicate increasing bottom current activity.

The constant abundance of Spiniferites cpx., Operculodinium spp., Hystrichokolpoma spp. and Lingulodinium machaerophorum as well as the low abundance of the typical cold-water indicator Gelatia inflata indicate the relatively constant influence of warm water (Egger et al., 2018), in line with indications of subtropical to warm temperate and always above freezing Australian hinterlands (Greenwood and Wing, 1995; Holdgate et al., 2017). Although, assemblages vary somewhat from sample to sample, there is no large change in the relative proportion of the main components of the assemblage throughout this interval that would suggest a change in oceanographic conditions. The exception is the occurrence of Svalbardella spp. in magnetochron C9n. The study of van Simaeys et al. (2005) linked the migration of Svalbardella spp. to the Southern Hemisphere during the second large benthic $\delta^{18} \mathrm{O}$ excursion in the Oligocene, the Oi-2b glacial episode (Miller et al., 1991; Zachos et al., 1994; Pekar et al., 2002). The sudden occurrence of Svalbardella spp. indicates that Antarctic cooling and glacial expansion also affected the distal sites in the Southern Ocean.

\subsubsection{Late Oligocene-early Miocene (P3: 25.5-20 Ma)}

In the late Oligocene, we note a sharp decrease in the neritic dinocyst groups (mostly Cleistosphaeridium cpx.) as well as a further increased dominance of Spiniferites spp. and more abundant oceanic taxa (Impagidinium spp. and $\mathrm{Ne}$ matosphaeropsis labyrinthus). This corroborates the continuous subsidence of the Tasmanian region (Stickley et al., 2004a), shifting depositional environments from a restricted inner-neritic basin to the deposition of carbonate ooze in a well-oxygenated open ocean along a continental slope at middle bathyal depths (Exon et al., 2001a, b; Boreham et al., 2002). The sediment wave features found in the lower part of Unit II seem to mostly disappear in the upper part of Unit II during the early Miocene, which is potentially caused by the continuous deepening of the margin.

Impagidinium paradoxum, the most abundant of the Impagidinium group, which starts to become more abundant at $25.5 \mathrm{Ma}$, is today most abundant in samples within $5^{\circ}$ latitude north or south of the STF (Prebble et al., 2013) (Fig. 3). Nematosphaeropsis labyrinthus, today most common south of the STF (Prebble et al., 2013) in the subantarctic zone, also increases in abundance from $25.5 \mathrm{Ma}$ onwards, peaking in the early Miocene. This could indicate northward expansion of the frontal systems and an approaching subantarctic zone towards Site 1168 in the late Oligocene-early Miocene. The very low abundance of the warm-water-affiliated taxa Hystrichokolpoma rigaudiae (e.g. Louwye et al., 2008) and Lingulodinium machaerophorum (e.g. De Schepper et al., 2011) suggest a slight cooling in the early Miocene compared with the late Oligocene.

\subsection{Tectonic and palaeoceanographic changes in the Tasmanian region}

\subsubsection{Seismic and lithological evidence of changing oceanographic conditions}

A shallow connection between the AAG and the southwest Pacific across the southwestern South Tasmanian Rise has existed since $\sim 49$ Ma near the Antarctic continental margin (Bijl et al., 2013) and perhaps since $\sim 38 \mathrm{Ma}$ across or north of the South Tasmanian Rise (Stickley et al., 2004a). However, the proto-Leeuwin Current (PLC), which transported warm subtropical waters into the AAG during the Eocene (Huber et al., 2004; Bijl et al., 2011; Sauermilch et al., 2019a), did not cross the Tasmanian Gateway until 35.5 Ma (Stickley et al., 2004a; Houben et al., 2019). Lithological barriers west and/or south of the Tasmanian rise, e.g. the Tasman Fracture Zone (TFZ), potentially restricted throughflow across the Tasmanian Gateway (Exon et al., 2004; Sauermilch et al., 2019a), which we here see diminished after the EOT, when graben have filled and continental margins subside.

The strongly different seismic structure of the continental slope on either side of the TFZ indicates that the TFZ and the extended Sorell Fault Zone played a significant role in the depositional evolution of the region during the Eocene and early Oligocene, and likely also affected ocean circulation flow. The South Tasman Rise and adjacent margins started to subside between 35.5 and $30.2 \mathrm{Ma}$, in conjunction with the final break-up between Australia and Antarctica (Cande and Stock, 2004; Whittaker et al., 2013; Williams et al., 2019; Mccarthy et al., 2020). This coincided with the sediment filling of embedded basins, draping the local expressions of the basement highs and leading to a depositional environment of a deepening continental slope.

Results from high-resolution ocean model simulations suggests that, during the time between 36 and $33.6 \mathrm{Ma}$, deepening of one of the gateways (Drake Passage or Tasmanian Gateway) below $300 \mathrm{~m}$ whilst the second gateway was already open (Sauermilch et al., 2021) could, in part, explain some of the oceanographic changes showed in available proxy records from Southern Ocean sediment drill cores (e.g. Houben et al., 2019; Westerhold et al., 2020). In the simulation (Sauermilch et al., 2021), depth changes from 300 to $600 \mathrm{~m}$ led to prominent surface water cooling offshore of Antarctica, whilst the subpolar gyres (Weddell and Ross gyres) weakened and shrank significantly and an eastward proto-Antarctic Circumpolar Current that was weaker than the present day current could be established. Model-data comparison suggests further gateway deepening $(>600 \mathrm{~m})$ occurring from 33.6 to $30 \mathrm{Ma}$, likely leading to stronger bottom-water currents passing through the Tasmanian Gate- 
a)

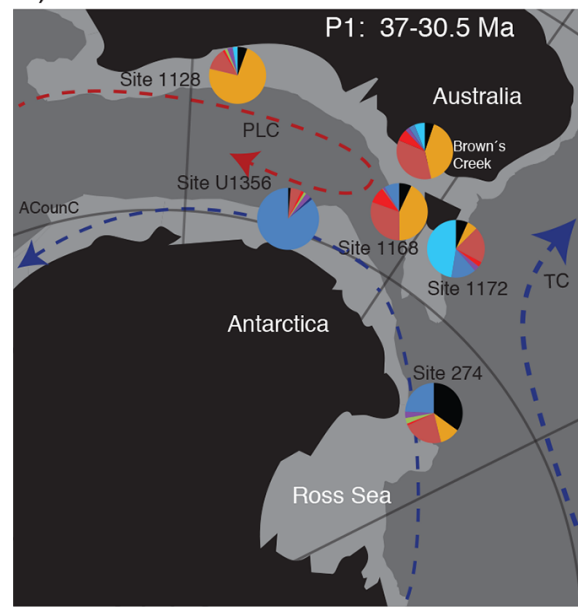

Dinocyst assemblage groups

Nematosphaeropsis spp. b)

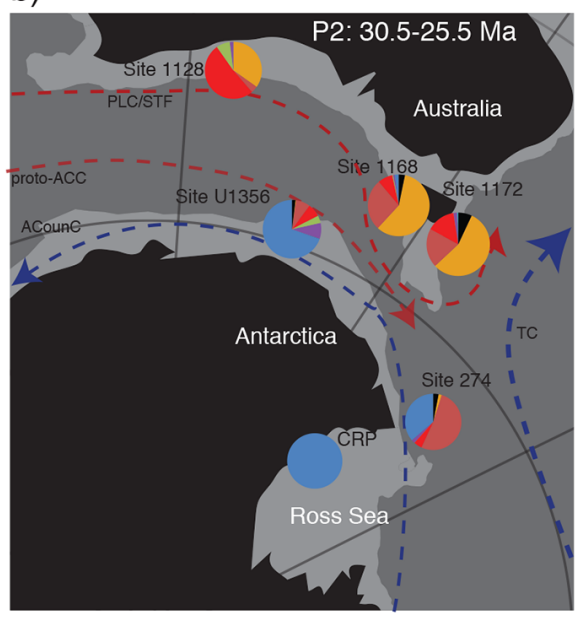

Extinct Peridinioid Protoperidinioid

Operculodinium spp.
Neritic G-cyst c)

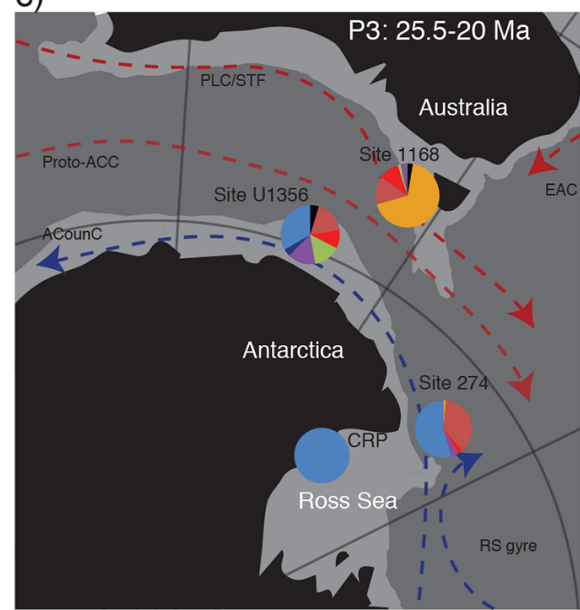

Figure 6. Dinocyst biogeographic patterns in the Tasmanian sector in three time slices in the late Eocene-early Miocene: (a) 37-30.5 Ma (31 data points), (b) $30.5-25 \mathrm{Ma}$ (42 data points) and (c) 25-20 Ma (50 data points). The dinocyst assemblage of ODP Site 1168 (this study) is presented along with that from IODP Site U1356 (Bijl et al., 2018), DSDP Site 274 (Hoem et al., 2021a), Cape Roberts Project (CRP) (Clowes et al., 2016), ODP Site 1172 (Sluijs et al., 2003), Site 1128 and Browns Creek (Houben et al., 2019) (Table S3 in the Supplement). The dinocyst taxa and/or ecological groups are indicated by different colours (see legend), following interpretations by Röhl et al. (2004) and Frieling and Sluijs. (2018). The "extinct peridinioid" group consists of Phthanoperidinium spp., Spinidinium spp. and Vozzhennikovia spp., Deflandrea phosphoritica and the Wetzelielloideae group. The blue and red stippled lines with arrows indicate flow direction, with proposed cool (blue) and warm (red) ocean currents that may have prevailed in the indicated areas during the different time intervals (e.g. Stickley et al., 2004a). EAC is the East Australian Current, PLC is the proto-Leeuwin Current, STF is the subtropical front, TC is the Tasman Current, proto-ACC is the proto-Antarctic Circumpolar Current and ACountC is the Antarctic Counter Current. The palaeogeographic position of the sites is generated with GPlates (http://www.gplates.org, last access: 13 June 2016), based on the global plates geodynamic motion model from Müller et al. (2018). Light grey indicates the continental shelf.

way. Between 32 and $30 \mathrm{Ma}$, the first deep-water current to pass the Tasmanian Gateway was flowing westward from the Pacific to the Indian Ocean (Scher et al., 2015), perhaps in compensation for the throughflow of the PLC. By $30.2 \mathrm{Ma}$, the Tasmanian Gateway was deep enough to fully connect the former AAG and the southern Pacific through the eastward flow of water masses originating within the AAG or southeastern Indian Ocean (Sluijs et al., 2003; Stickley et al., 2004a). Sediment waves observed in seismic data from the early until the late Oligocene (partly until the earliest Miocene) support this hypothesis. Sites around the Southern Ocean have quasi-synchronous glauconite horizons, caused by current winnowing and sediment starvation, and are often condensed, such as Unit IV and lower Unit III at Site 1168 (Houben et al., 2019; Sauermilch et al., 2019a). These are equivalent to a widespread known regional unconformity, the Marshall unconformity (Carter, 1985; Fulthorpe et al., 1996). Stickley et al. (2004a) associated the Tasmanian glauconite intervals with accelerated subsidence of the South Tasman continental blocks, while Houben et al. (2019), who recorded the late Eocene glauconite sands as a Southern Ocean-wide phenomenon, linked them to invigorated surface current intensity where progressive pre-EOT atmospheric cooling played a defining role.

\subsubsection{Palynological evidence of sea surface ecological changes across the widening Southern Ocean}

To provide a wider, Southern Ocean perspective to the results of ODP Site 1168 during these times of Tasmanian Gateway widening, we compare palynological data from different drill sites in the region for the same time intervals (phases 1-3) as in Sect. 5.2 (Fig. 6).

Ice-proximal palynological records from the Ross Sea shelf, Cape Roberts Project (CRP) (Prebble et al., 2006; Clowes et al., 2016), are dominated by Lejeunecysta spp., and Cymatiosphaera spp. in the Oligocene with the addition of Brigantedinium spp. in the late Oligocene-early Miocene (Hannah et al., 2000; Prebble et al., 2006; Clowes et al., 2016). This likely indicates generally cold temperate, nutrient-rich, productive waters where seasonal sea ice melts. The more distal locations, DSDP sites 269 and 274 and IODP Site U1356, are bathed by temperate waters (Bijl et al., 2018; Sangiorgi et al., 2018; Hartman et al., 2018b; Salabarnada 
et al., 2018; Evangelinos et al., 2020; Hoem et al., 2021a) and represented open-ocean high-nutrient conditions of the Antarctic divergence. Our study shows that ocean waters at the Australian margin in the late Eocene-early Miocene resembled those of modern subtropical water near-shore sites north of New Zealand (Prebble et al., 2013), despite the more southerly position of Australia. This shows a strong differentiation in dinocyst assemblages at either side of the AAG starting in the late Eocene and increasing in the Oligocene $(<30.5 \mathrm{Ma})$ to early Miocene, indicating that the frontal systems were evolving in place, which contrasts with the early Eocene conditions (e.g. Bijl et al., 2013) (Fig. 6).

The intensified deepening and widening of the Tasmanian Gateway between $\sim 35.5$ and $30.2 \mathrm{Ma}$ facilitated the throughflow of the PLC (Stickley et al., 2004a, b). After $30.2 \mathrm{Ma}$, we record that this throughflow caused profound changes in the dinocyst assemblages on the east side of the Tasmanian Gateway (ODP Site 1172; Sluijs et al., 2003), with the disappearance of the Antarctic-derived "extinct peridinioid" cysts and an increase in cosmopolitan dinocyst species, making the dinocyst assemblages strikingly similar at Site 1168 and Site 1172 for P2 (Fig. 6b). However, at Site 1168, the throughflow was of little influence. Indeed, deepening of the continental slope does limit the input of coastal dinoflagellate cyst species and terrestrial palynomorphs, but it does not profoundly alter the remaining outer-neritic to oceanic dinocyst assemblage. This testifies to a continuous influence of the PLC. South Australian surfaceocean conditions remained surprisingly invariant to largescale Antarctic glaciation, onset of circumpolar flow (Stickley et al., 2004a; Sijp et al., 2014) and appearance of Antarctic sea ice (Houben et al., 2013), despite its southerly position. Indeed, circumpolar flow through the Tasmanian Gateway was likely still slow throughout the Oligocene (Hill et al., 2013; Evangelinos et al., 2020; Sauermilch et al., 2021).

\subsubsection{Environmental interpretation of acritarchs and prasinophyte algae across the Southern Ocean}

The peak of Acritarch sp. 2 around 26.8-25.8 Ma (550$520 \mathrm{mb}$ b.s.f.) and Acritarch sp. 1 bloom from $22.3 \mathrm{Ma}$ (400 m b.s.f.) (Fig. 5) occur around the same time as a slight decrease in sedimentation rate (Fig. 2) and coincide with the high carbonate $\left(\mathrm{CaCO}_{3}\right)$ content (Fig. 4) (Pfuhl and Mccave, 2003). The first acritarch bloom is not observed at the other Southern Ocean sites in the vicinity of the Tasmanian Gateway but correlates with carbonate-rich and iceberg-rafted debris free interglacial sediments at IODP Site U1356 between 25 and $26 \mathrm{Ma}$ (Salabarnada et al., 2018). The Site 1168 peak in acritarchs in the early Miocene is comparable and coeval to that in a carbonate- rich intervals of IODP Site U1356 (Bijl et al., 2018), where "Cymatiosphaera-like" acritarchs dominate the assemblages of the late Oligocene $(<24.5 \mathrm{Ma})$ to mid-Miocene. Carbonate- rich intervals during the late Oligocene-early Miocene at Site U1356, along with olig- otrophic, temperate dinocysts suggest a trend of increased acritarch abundance during warmer intervals. However, due to little indication of warming in the early Miocene in the dinocyst record or the benthic foraminiferal $\delta^{18} \mathrm{O}$ record by Westerhold et al. (2020), we suggest the higher $\mathrm{CaCO}_{3}$ at Site 1168 to reflect a transition in lithology linked to changes in environmental conditions, likely due to decreased detrital input as a consequence of decreased precipitation in the hinterland (McGowran et al., 2004). At DSDP Site 269, Leiosphaera spp. is the most common palynomorph in the upper Oligocene-lower Miocene (Evangelinos et al., 2020). At DSDP Site 274, acritarch assemblages (mainly skolochorate, similar to our Acritarch sp. 1) are relatively low ( $<30 \%)$ throughout the lower Oligocene but increase towards the upper Oligocene (Hoem et al., 2021a). Acritarch blooms in each of the various records analysed seem to be linked to a different environmental condition. Therefore, we cannot identify a main environmental driver of acritarch blooms across the Southern Ocean during the late Oligocene-early Miocene.

\section{Conclusions}

We present new seismic interpretations and marine palynological association data to reconstruct the late Eocene to early Miocene palaeoceanographic conditions on the western Tasmanian continental margin. Upper Eocene sediments are embedded in a sedimentary basin enclosed by two basement highs, whereas material of EOT-earliest Oligocene age draped basement highs and show some indications of sediment reworking and winnowing. In the Oligocene to lower Miocene units, seismic features show evidence of bottom current activity. The Tasmanian Fracture Zone and the Sorell Fault Zone likely acted as a bathymetric barrier for ocean currents to reach Site 1168 during the late Eocene. Possible buoyancy-related uplift of the region through subcontinental mantle exhumation (Fig. 1c) during this time may have added to the bathymetric isolation effect. Palynological data confirm these seismic interpretations of the subsidence of the Tasmanian continental margin (Stickley et al., 2004a), with a transition from abundant terrestrial palynomorphs, Protoperidinioid cysts and extant neritic dinocysts in the total palynological counts in the late Eocene to the increasing abundance of modern oceanic dinocyst groups through the Oligocene-early Miocene. The different dinocyst assemblages north and south across the widening Southern Ocean reflect the onset of modern oceanographic conditions with a pronounced latitudinal temperature gradient starting in the late Eocene, manifesting itself in the Oligocene with more established frontal systems in the Southern Ocean. We suggest a northward broadening of the STF and subantarctic zone towards Site 1168 in the early Miocene. Aside from the gradual disappearance of inner-neritic-neritic species through the Oligocene record and the introduction of oceanic species common south of the STF (subantarctic zone), there are no 
significant changes to the surface-ocean properties or ocean currents at the western Tasmanian marginal Site 1168 in the Oligocene.

Data availability. All microscope slides are housed at Utrecht University (LPP 069, 070, 129, 803 and 804). The data sets are stored on the Zenodo data archive: https://doi.org/10.5281/zenodo.5529715 (Hoem et al., 2021b).

Supplement. The supplement related to this article is available online at: https://doi.org/10.5194/jm-40-175-2021-supplement.

Author contributions. PKB and FS designed the research. FSH, $\mathrm{PKB}$ and $\mathrm{HB}$ collected or requested the samples. PKB converted the age model to the GTS2012 timescale. IS requested, described and interpreted the seismic data. FSH processed samples for palynology and counted 105 slides. SH counted 18 of the slides from the Miocene. FSH, PKB and FS interpreted the palynomorph data. FSH wrote the paper with input from all co-authors.

Competing interests. Francesca Sangiorgi, co-author of this paper, is editor-in-chief of Journal of Micropalaeontology. Luke Mander operated as handling editor for this paper.

Disclaimer. Publisher's note: Copernicus Publications remains neutral with regard to jurisdictional claims in published maps and institutional affiliations.

Acknowledgements. Sediment samples were provided by the Ocean Drilling Program (ODP). We thank Natasja Welters, Mariska Hoorweg and Giovanni Dammers for technical support at the Utrecht University GeoLab. We thank Spectrum Geo Ltd and the Federal Institute for Geosciences and Natural Resources Germany for providing the seismic reflection data sets. We acknowledge IHS Markit for the provision of the IHS Kingdom software used in this research.

Financial support. This research has been supported by the Dutch Research councile, Nederlandse Organisatie voor Wetenschappelijk Onderzoek (NWO) polar programme (grant no. ALW.2016.001), and the European Research Council, H2020 programme (grant no. OceaNice 802835).

Review statement. This paper was edited by Luke Mander and reviewed by Marcelo De Lira Mota and one anonymous referee.

\section{References}

Amoo, M., Salzmann, U., Pound, M. J., Thompson, N., and Bijl, P. K.: Eocene to Oligocene vegetation and climate in the Tasmanian Gateway region controlled by changes in ocean currents and $p \mathrm{CO}_{2}$, Clim. Past Discuss. [preprint], https://doi.org/10.5194/cp-2021-131, in review, 2021.

Bijl, P. K., Pross, J., Warnaar, J., Stickley, C. E., Huber, M., Guerstein, R., Houben, A. J., Sluijs, A., Visscher, H., and Brinkhuis, H.: Environmental forcings of Paleogene Southern Ocean dinoflagellate biogeography, Paleoceanography, 26, PA1202, https://doi.org/10.1029/2009PA001905, 2011.

Bijl, P. K., Bendle, J. A., Bohaty, S. M., Pross, J., Schouten, S., Tauxe, L., Stickley, C. E., McKay, R. M., Rohl, U., Olney, M., Sluijs, A., Escutia, C., Brinkhuis, H., and Expedition 318 scientists: Eocene cooling linked to early flow across the Tasmanian Gateway, P. Natl. Acad. Sci. USA, 110, 9645-9650, https://doi.org/10.1073/pnas.1220872110, 2013.

Bijl, P. K., Houben, A. J., Hartman, J. D., Pross, J., Salabarnada, A., Escutia, C., and Sangiorgi, F.: Paleoceanography and ice sheet variability offshore Wilkes Land, Antarctica-Part 2: Insights from Oligocene-Miocene dinoflagellate cyst assemblages, Clim. Past, 14, 1015-1033, https://doi.org/10.5194/cp-14-10152018, 2018.

Boreham, C., Blevin, J., Duddy, I., Newman, J., Liu, K., Middleton, H., Macphail, M., and Cook, A.: Exploring the potential for oil generation, migration and accumulation in Cape Sorell-1, Sorell Basin, offshore West Tasmania, APPEA J., 42, 405-435, https://doi.org/10.1071/AJ01022, 2002.

Brinkhuis, H.: Late Eocene to Early Oligocene dinoflagellate cysts from the Priabonian type-area (Northeast Italy): biostratigraphy and paleoenvironmental interpretation, Palaeogeogr. Palaeocl., 107, 121-163, https://doi.org/10.1016/0031-0182(94)90168-6, 1994.

Brinkhuis, H. and Biffi, U.: Dinoflagellate cyst stratigraphy of the Eocene/Oligocene transition in central Italy, Mar. Micropaleontol., 22, 131-183, https://doi.org/10.1016/0377-8398(93)90007K, 1993.

Brinkhuis, H., Munsterman, D., Sengers, S., Sluijs, A., Warnaar, J., and Williams, G.: Late Eocene to Quaternary dinoflagellate cysts from ODP Site 1168, Off western Tasmania, Proceedings of the Ocean Drilling Program, Scientific Results, 189, 1-36, https://doi.org/10.2973/odp.proc.sr.189.105.2003, 2003.

Cande, S. C. and Stock, J. M.: Pacific-Antarctic-Australia motion and the formation of the Macquarie Plate, Geophys. J. Int., 157, 399-414, https://doi.org/10.1111/j.1365246X.2004.02224.x, 2004.

Carter, R.: The mid-Oligocene Marshall Paraconformity, New Zealand: coincidence with global eustatic sea-level fall or rise?, J. Geol., 93, 359-371, https://doi.org/10.1086/628957, 1985.

Clowes, C. D., Hannah, M. J., Wilson, G. J., and Wrenn, J. H.: Marine palynostratigraphy and new species from the Cape Roberts drill-holes, Victoria land basin, Antarctica, Mar. Micropaleontol., 126, 65-84, https://doi.org/10.1016/j.marmicro.2016.06.003, 2016.

Crouch, E., Mildenhall, D., and Neil, H.: Distribution of organicwalled marine and terrestrial palynomorphs in surface sediments, offshore eastern New Zealand, Mar. Geol., 270, 235-256, https://doi.org/10.1016/j.earscirev.2019.102961, 2010. 
Dale, B.: Dinoflagellate cyst ecology: modeling and geological applications, Palynology: principles and applications, AASP Found., College Station, Texas, USA, 1249-1275, 1996.

De Schepper, S. and Head, M. J.: New late Cenozoic acritarchs: evolution, palaeoecology and correlation potential in high latitude oceans, J. System. Palaeontol., 12, 493-519, https://doi.org/10.1080/14772019.2013.783883, 2014.

De Schepper, S., Fischer, E. I., Groeneveld, J., Head, M. J., and Matthiessen, J.: Deciphering the palaeoecology of Late Pliocene and Early Pleistocene dinoflagellate cysts, Palaeogeogr. Palaeocl., 309, 17-32, https://doi.org/10.1016/j.palaeo.2011.04.020, 2011.

Egger, L. M., Bahr, A., Friedrich, O., Wilson, P. A., Norris, R. D., Van Peer, T. E., Lippert, P. C., Liebrand, D., and Pross, J.: Sea-level and surface-water change in the western North Atlantic across the Oligocene-Miocene Transition: a palynological perspective from IODP Site U1406 (Newfoundland margin), Mar. Micropaleontol., 139, 57-71, https://doi.org/10.1016/j.marmicro.2017.11.003, 2018.

Evangelinos, D., Escutia, C., Etourneau, J., Hoem, F., Bijl, P., Boterblom, W., van de Flierdt, T., Valero, L., Flores, J.A., Rodriguez-Tovar, F. J., Jimenez-Espejo, F. J., Salabarnada, A., and López-Quirós, A.: Late Oligocene-Miocene protoAntarctic Circumpolar Current dynamics off the Wilkes Land margin, East Antarctica, Glob. Planet. Change, 191, 103221, https://doi.org/10.1016/j.gloplacha.2020.103221, 2020.

Evitt, W. R.: A discussion and proposals concerning fossil dinoflagellates, hystrichospheres, and acritarchs, I, P. Natl. Acad. Sci. USA, 49, 158-164, 1963.

Exon, N. F., Kennett, J. P., Malone, M. J., and the Leg189 Shipboard Scientific Party: Leg 189 summary, Proceedings of the Ocean Drilling Program Initial Reports, Ocean Drilling Program, College Station, TX, USA, 2001a.

Exon, N. F., Kennett, J. P., Malone, M. J., and the Leg189 Shipboard Scientific Party: Site 1168. , Proceedings of the Ocean Drilling Program Initial Reports, Ocean Drilling Program, College Station, TX, USA, 2001b.

Exon, N. F., Kennett, J. P., and Malone, M. J.: Leg 189 synthesis: Cretaceous-Holocene history of the Tasmanian gateway, Proceedings of the ocean drilling program, Scientific Results, 189, 1-37, https://doi.org/10.2973/odp.proc.sr.189.101.2004, 2004.

Fensome, R. A.: A classification of living and fossil dinoflagellates, Micropaleontology, Special Publication, 7, 1-351, 1993.

Frieling, J. and Sluijs, A.: Towards quantitative environmental reconstructions from ancient non-analogue microfossil assemblages: Ecological preferences of Paleocene - Eocene dinoflagellates, Earth-Sci. Rev., 185, 956-973, https://doi.org/10.1016/j.earscirev.2018.08.014, 2018.

Fulthorpe, C. S., Carter, R. M., Miller, K. G., and Wilson, J.: Marshall Paraconformity: a mid-Oligocene record of inception of the Antarctic circumpolar current and coeval glacio-eustatic lowstand?, Mar. Petrol. Geol., 13, 61-77, https://doi.org/10.1016/0264-8172(95)00033-X, 1996.

Galeotti, S., DeConto, R., Naish, T., Stocchi, P., Florindo, F., Pagani, M., Barrett, P., Bohaty, S. M., Lanci, L., Pollard, D., Sandroni, S., Talarico, F. M., and Zachos, J. C.: Antarctic Ice Sheet variability across the EoceneOligocene boundary climate transition, Science, 352, 76-80, https://doi.org/10.1126/science.aab0669, 2016.
Gallagher, S. J., Villa, G., Drysdale, R. N., Wade, B. S., Scher, H., Li, Q., Wallace, M. W., and Holdgate, G. R.: A near-field sea level record of East Antarctic Ice Sheet instability from 32 to $27 \mathrm{Myr}$, Paleoceanography, 28, 1-13, https://doi.org/10.1029/2012PA002326, 2013.

Gallagher, S. J., Wade, B., Qianyu, L., Holdgate, G. R., Bown, P., Korasidis, V. A., Scher, H., Houben, A. J., McGowran, B., and Allan, T.: Eocene to Oligocene high paleolatitude neritic record of Oi-1 glaciation in the Otway Basin southeast Australia, Glob. Planet. Change, 191, 103218, https://doi.org/10.1016/j.gloplacha.2020.103218, 2020.

Gillard, M., Autin, J., Manatschal, G., Sauter, D., Munschy, M., and Schaming, M.: Tectonomagmatic evolution of the final stages of rifting along the deep conjugate Australian-Antarctic magmapoor rifted margins: Constraints from seismic observations, Tectonics, 34, 753-783, https://doi.org/10.1002/2015TC003850, 2015.

Gradstein, F. M., Ogg, J. G., Schmitz, M. D., and Ogg, G. M.: The Geologic Time Scale 2012, The Geologic Time Scale, 2, 4371144, 2012.

Greenwood, D. R. and Wing, S. L.: Eocene continental climates and latitudinal temperature gradients, Geology, 23, 1044-1048, 1995.

Guerstein, G. R., Guler, M. V., Williams, G. L., Fensome, R. A., and Chiesa, J. O.: Middle Palaeogene dinoflagellate cysts from Tierra del Fuego, Argentina: biostratigraphy and palaeoenvironments, J. Micropalaeontol., 27, 75-94, https://doi.org/10.1144/jm.27.1.75, 2008.

Hannah, M., Wrenn, J., and Wilson, G.: Early Miocene and Quaternary marine palynomorphs from Cape Roberts Project CRP-1, McMurdo Sound, Antarctica, Terra Antartica, 5, 527-538, 1998.

Hannah, M., Wilson, G., and Wrenn, J.: Oligocene and miocene marine palynomorphs from CRP-2/2A, Victoria Land Basin, Antarctica, Terra Antartica, 7, 503-511, 2000.

Hannah, M. J.: The palynology of ODP site 1165, Prydz Bay, East Antarctica: a record of Miocene glacial advance and retreat, Palaeogeogr. Palaeocl., 231, 120-133, https://doi.org/10.1016/j.palaeo.2005.07.029, 2006.

Harland, R. and Pudsey, C. J.: Dinoflagellate cysts from sediment traps deployed in the Bellingshausen, Weddell and Scotia seas, Antarctica, Mar. Micropaleontol., 37, 77-99, 1999.

Hartman, J. D., Bijl, P. K., and Sangiorgi, F.: A review of the ecological affinities of marine organic microfossils from a Holocene record offshore of Adélie Land (East Antarctica), J. Micropalaeontol., 37, 445-497, https://doi.org/10.5194/jm-37445-2018, 2018a.

Hartman, J. D., Sangiorgi, F., Salabarnada, A., Peterse, F., Houben, A. J. P., Schouten, S., Brinkhuis, H., Escutia, C., and Bijl, P. K.: Paleoceanography and ice sheet variability offshore Wilkes Land, Antarctica - Part 3: Insights from Oligocene-Miocene TEX86-based sea surface temperature reconstructions, Clim. Past, 14, 1275-1297, https://doi.org/10.5194/cp-14-1275-2018, 2018b.

Head, M.: Modern dinoflagellate cysts and their biological affinities, Palynology, 3, 1197-1248, 1996.

Hill, D. J., Haywood, A. M., Valdes, P. J., Francis, J. E., Lunt, D. J., Wade, B. S., and Bowman, V. C.: Paleogeographic controls on the onset of the Antarctic circumpolar current, Geophys. Res. Lett., 40, 5199-5204, https://doi.org/10.1002/grl.50941, 2013. 
Hill, P., Meixner, A., Moore, A., and Exon, N.: Structure and development of the west Tasmanian offshore sedimentary basins: results of recent marine and aeromagnetic surveys, Austr. J. Earth Sci., 44, 579-596, https://doi.org/10.1080/08120099708728338, 1997.

Hill, P. J. and Exon, N. F.: Tectonics and basin development of the offshore Tasmanian area incorporating results from deep ocean drilling, Washington DC American Geophysical Union, Geophysical Monograph Series, 151, 19-42, https://doi.org/10.1029/151GM03, 2004.

Hochmuth, K., Gohl, K., Leitchenkov, G., Sauermilch, I., Whittaker, J. M., Uenzelmann-Neben, G., Davy, B., and De Santis, L.: The evolving paleobathymetry of the circum-Antarctic Southern Ocean since $34 \mathrm{Ma}$ - a key to understanding past cryosphere-ocean developments, Geochem. Geophy. Geosy., 11, e2020GC009122, https://doi.org/10.1029/2020GC009122, 2020.

Hoem, F. S., Valero, L., Evangelinos, D., Escutia, C., Duncan, B., McKay, R. M., Brinkhuis, H., Sangiorgi, F., and Bijl, P. K.: Temperate Oligocene surface ocean conditions offshore of Cape Adare, Ross Sea, Antarctica, Clim. Past, 17, 1423-1442, https://doi.org/10.5194/cp-17-1423-2021, 2021a.

Hoem, F. S., Sauermilch, I., Hou, S., Brinkhuis, H., Sangiorgi, F., and Bijl, P. K.: Late Eocene-early Miocene evolution of the southern Australian Subtropical Front: a marine palynological approach, Zenodo [data set], https://doi.org/10.5281/zenodo.5529715, 2021b.

Holdgate, G., Sluiter, I., and Taglieri, J.: Eocene-Oligocene coals of the Gippsland and Australo-Antarctic basins-Paleoclimatic and paleogeographic context and implications for the earliest Cenozoic glaciations, Palaeogeogr. Palaeocl., 472, 236-255, https://doi.org/10.1016/j.palaeo.2017.01.035, 2017.

Houben, A. J., Bijl, P. K., Pross, J., Bohaty, S. M., Passchier, S., Stickley, C. E., Rohl, U., Sugisaki, S., Tauxe, L., van de Flierdt, T., Olney, M., Sangiorgi, F., Sluijs, A., Escutia, C., Brinkhuis, H., and Expedition 318 scientists: Reorganization of Southern Ocean plankton ecosystem at the onset of Antarctic glaciation, Science, 340, 341-344, https://doi.org/10.1126/science.1223646, 2013.

Houben, A. J. P., Bijl, P. K., Sluijs, A., Schouten, S., and Brinkhuis, H.: Late Eocene Southern Ocean Cooling and Invigoration of Circulation Preconditioned Antarctica for FullScale Glaciation, Geochem. Geophy. Geosy., 20, 2214-2234, https://doi.org/10.1029/2019gc008182, 2019.

Huber, M., Brinkhuis, H., Stickley, C. E., Döös, K., Sluijs, A., Warnaar, J., Schellenberg, S. A., and Williams, G. L.: Eocene circulation of the Southern Ocean: Was Antarctica kept warm by subtropical waters?, Paleoceanography, 19, 4, https://doi.org/10.1029/2004PA001014, 2004.

Hutchinson, D. K., Coxall, H. K., Lunt, D. J., Steinthorsdottir, M., de Boer, A. M., Baatsen, M., von der Heydt, A., Huber, M., Kennedy-Asser, A. T., and Kunzmann, L.: The EoceneOligocene transition: a review of marine and terrestrial proxy data, models and model-data comparisons, Clim. Past, 17, 269315, https://doi.org/10.5194/cp-17-269-2021, 2021.

Lawver, L. A., Gahagan, L. M., and Coffin, M. F.: The development of paleoseaways around Antarctica, Ant. Res. Ser., 56, 7 30, 1992.

Louwye, S., Foubert, A., Mertens, K., and Van Rooij, D.: Integrated stratigraphy and palaeoecology of the Lower and Mid- dle Miocene of the Porcupine Basin, Geol. Mag., 145, 321-344, https://doi.org/110.1017/S0016756807004244, 2008.

Marret, F., Bradley, L., de Vernal, A., Hardy, W., Kim, S.-Y., Mudie, P., Penaud, A., Pospelova, V., Price, A. M., Radi, T., and Rochon, A.: From bi-polar to regional distribution of modern dinoflagellate cysts, an overview of their biogeography, Mar. Micropaleontol., 159, 101753, https://doi.org/10.1016/j.marmicro.2019.101753, 2020.

Matthews, K. J., Maloney, K. T., Zahirovic, S., Williams, S. E., Seton, M., and Mueller, R. D.: Global plate boundary evolution and kinematics since the late Paleozoic, Glob. Planet. Change, 146, 226-250, https://doi.org/10.1016/j.gloplacha.2016.10.002, 2016.

McCarthy, A., Falloon, T., Sauermilch, I., Whittaker, J., Niida, K., and Green, D.: Revisiting the Australian-Antarctic ocean-continent transition zone using petrological and geophysical characterization of exhumed subcontinental mantle, Geochem. Geophy. Geosy., 21, e2020GC009040, https://doi.org/10.1029/2020GC009040, 2020.

McGowran, B., Holdgate, G., Li, Q., and Gallagher, S.: Cenozoic stratigraphic succession in southeastern Australia, Austr. J. Earth Sci., 51, 459-496, https://doi.org/10.1111/j.14000952.2004.01078.x, 2004.

Mertens, K. N., Verhoeven, K., Verleye, T., Louwye, S., Amorim, A., Ribeiro, S., Deaf, A. S., Harding, I. C., De Schepper, S., and González, C.: Determining the absolute abundance of dinoflagellate cysts in recent marine sediments: the Lycopodium markergrain method put to the test, Rev. Palaeobot. Palyno., 157, 238252, https://doi.org/10.1016/j.revpalbo.2009.05.004, 2009.

Miller, J. M., Norvick, M. S., and Wilson, C. J.: Basement controls on rifting and the associated formation of ocean transform faults - Cretaceous continental extension of the southern margin of Australia, Tectonophysics, 359, 131-155, https://doi.org/10.1016/S0040-1951(02)00508-5, 2002.

Miller, K. G., Wright, J. D., and Fairbanks, R. G.: Unlocking the ice house: Oligocene-Miocene oxygen isotopes, eustasy, and margin erosion, J. Geophys. Res.-Sol. Ea., 96, 6829-6848, https://doi.org/10.1029/90JB02015, 1991.

Mudie, P.: Neogene and quaternary dinoflagellate cysts and acritarchs, Second Symposium on Neogene Dinoflagellates, American Association of Stratigraphic Palynologists, Dallas, USA, 347-390, 1992.

Mudie, P. J., Marret, F., Gurdebeke, P. R., Hartman, J. D., and Reid, P. C.: Marine dinocysts, acritarchs and less well-known NPP: tintinnids, ostracod and foraminiferal linings, copepod and worm remains, Geol. Soc. Lond. Sp. Publ., 511, 159-232, https://doi.org/10.1144/SP511-2020-55, 2021.

Müller, R. D., Cannon, J., Qin, X., Watson, R. J., Gurnis, M., Williams, S., Pfaffelmoser, T., Seton, M., Russell, S. H., and Zahirovic, S.: GPlates: building a virtual Earth through deep time, Geochem. Geophy. Geosy., 19, 2243-2261, https://doi.org/10.1029/2018GC007584, 2018.

Müntener, O., Manatschal, G., Desmurs, L., and Pettke, T. Plagioclase peridotites in ocean-continent transitions: refertilized mantle domains generated by melt stagnation in the shallow mantle lithosphere, J. Petrol., 51, 255-294, https://doi.org/10.1093/petrology/egp087, 2010.

Nelson, C. S. and Cooke, P. J.: History of oceanic front development in the New Zealand sector of the Southern Ocean during the 
Cenozoic - a synthesis, New Zealand J. Geol. Geophys., 44, 535553, https://doi.org/10.1080/00288306.2001.9514954, 2001.

Orsi, A. H., Whitworth, T., and Nowlin, W. D.: On the meridional extent and fronts of the Antarctic Circumpolar Current, Deep-Sea Res. Pt. I, 42, 641-673, https://doi.org/10.1016/09670637(95)00021-w, 1995.

Palike, H., Norris, R. D., Herrle, J. O., Wilson, P. A., Coxall, H. K., Lear, C. H., Shackleton, N. J., Tripati, A. K., and Wade, B. S.: The heartbeat of the Oligocene climate system, Science, 314, 1894-1898, https://doi.org/10.1126/science.1133822, 2006.

Parke, M., Boalch, G., Jowett, R., and Harbour, D.: The genus Pterosperma (Prasinophyceae): species with a single equatorial ala, J. Mar. Biol. Assoc. UK, 58, 239-276, https://doi.org/10.1017/S0025315400024528, 1978.

Pascher, K. M., Hollis, C. J., Bohaty, S. M., Cortese, G., McKay, R. M., Seebeck, H., Suzuki, N., and Chiba, K.: Expansion and diversification of high-latitude radiolarian assemblages in the late Eocene linked to a cooling event in the southwest Pacific, Clim. Past, 11, 1599-1620, https://doi.org/10.5194/cp-11-1599-2015, 2015.

Pekar, S. F., Christie-Blick, N., Kominz, M. A., and Miller, K. G.: Calibration between eustatic estimates from backstripping and oxygen isotopic records for the Oligocene, Geology, 30, 903-906, https://doi.org/10.1130/00917613(2002)030<0903:CBEEFB>2.0.CO;2, 2002.

Pfuhl, H. A. and McCave, I. N.: Integrated age models for the early Oligocene-early Miocene, sites 1168 and 1170-1172, Proc. ODP, Sci. Results, 189, 1-21, https://doi.org/10.2973/odp.proc.sr.189.108.2003, 2003.

Prebble, J., Raine, J., Barrett, P., and Hannah, M.: Vegetation and climate from two Oligocene glacioeustatic sedimentary cycles (31 and $24 \mathrm{Ma}$ ) cored by the Cape Roberts Project, Victoria Land Basin, Antarctica, Palaeogeogr. Palaeocl., 231, 41-57, https://doi.org/10.1016/j.palaeo.2005.07.025, 2006.

Prebble, J. G., Crouch, E. M., Carter, L., Cortese, G., Bostock, H., and Neil, H.: An expanded modern dinoflagellate cyst dataset for the Southwest Pacific and Southern Hemisphere with environmental associations, Mar. Micropaleontol., 101, 33-48, https://doi.org/10.1016/j.marmicro.2013.04.004, 2013.

Pross, J. and Brinkhuis, H.: Organic-walled dinoflagellate cysts as paleoenvironmental indicators in the $\mathrm{Pa}-$ leogene; a synopsis of concepts, Palaont. Z., 79, 53-59, https://doi.org/10.1007/BF03021753, 2005.

Pross, J., Contreras, L., Bijl, P. K., Greenwood, D. R., Bohaty, S. M., Schouten, S., Bendle, J. A., Röhl, U., Tauxe, L., and Raine, J. I.: Persistent near-tropical warmth on the Antarctic continent during the early Eocene epoch, Nature, 488, 73-77, https://doi.org/10.1038/nature11300, 2012.

Ridgway, K. and Condie, S.: The 5500-km-long boundary flow off western and southern Australia, J. Geophys. Res.-Ocean., 109, C04017, https://doi.org/10.1029/2003JC001921, 2004.

Röhl, U., Brinkhuis, H., Sluijs, A., and Fuller, M.: On the search for the Paleocene/Eocene boundary in the Southern Ocean: exploring ODP Leg 189 Holes 1171D and 1172D, Tasman Sea, The Cenozoic Southern Ocean: Tectonics, Sesimentation, and Climate Change Between Australia and Antarctica, Geophys. Monogr. Ser., 151, 113-125, https://doi.org/10.1029/151GM08, 2004.
Salabarnada, A., Escutia, C., Röhl, U., Nelson, C. H., McKay, R., Jiménez-Espejo, F. J., Bijl, P. K., Hartman, J. D., Strother, S. L., and Salzmann, U.: Paleoceanography and ice sheet variability offshore Wilkes Land, Antarctica - Part 1: Insights from late Oligocene astronomically paced contourite sedimentation, Clim. Past, 14, 991-1014, https://doi.org/10.5194/cp-14-9912018, 2018.

Sangiorgi, F., Bijl, P. K., Passchier, S., Salzmann, U., Schouten, S., McKay, R., Cody, R. D., Pross, J., van de Flierdt, T., Bohaty, S. M., Levy, R., Williams, T., Escutia, C., and Brinkhuis, H.: Southern Ocean warming and Wilkes Land ice sheet retreat during the mid-Miocene, Nat. Commun., 9, 317-328, https://doi.org/10.1038/s41467-017-02609-7, 2018.

Sauermilch, I., Whittaker, J. M., Bijl, P. K., Totterdell, J., and Jokat, W.: Tectonic, oceanographic, and climatic controls on the Cretaceous-Cenozoic sedimentary record of the AustralianAntarctic Basin, J. Geophys. Res.-Sol. Ea., 124, 7699-7724, https://doi.org/10.1029/2018JB016683, 2019a.

Sauermilch, I., Mateo, Z. R. P., and Boaga, J.: A comparative analysis of time-depth relationships derived from scientific ocean drilling expeditions, Mar. Geophys. Res., 40, 635-641, https://doi.org/10.1007/s11001-019-09393-7, 2019b.

Sauermilch, I., Whittaker, J. M., Klocker, A., Munday, D. R., Hochmuth, K., LaCasce, J. H., and Bijl, P.: Gateway-driven Southern Ocean cooling - The crucial role of ocean gyres, Nat Commun., https://doi.org/10.1038/s41467-021-26658-1, 2021.

Scher, H. D., Whittaker, J. M., Williams, S. E., Latimer, J. C., Kordesch, W. E. C., and Delaney, M. L.: Onset of Antarctic Circumpolar Current 30 million years ago as Tasmanian Gateway aligned with westerlies, Nature, 523, 580, https://doi.org/10.1038/nature14598, 2015.

Schreck, M. and Matthiessen, J.: Batiacasphaera micropapillata: Palaeobiogeographic distribution and palaeoecological implications of a critical Neogene species complex, Biological and Geological Perspectives of Dinoflagellates, The Micropalaeontological Society, Sp. Publ. Geol. Soc. Lond., 5, 301-314, 2013.

Sijp, W. P., Anna, S., Dijkstra, H. A., Flögel, S., Douglas, P. M., and Bijl, P. K.: The role of ocean gateways on cooling climate on long time scales, Glob. Planet. Change, 119, 1-22, https://doi.org/10.1016/j.gloplacha.2014.04.004, 2014.

Sijp, W. P., Heydt, A. S., and Bijl, P. K.: Model simulations of early westward flow across the Tasman Gateway during the early Eocene, Clim. Past, 12, 807-817, https://doi.org/10.5194/cp-12807-2016, 2016.

Sluijs, A., Brinkhuis, H., Stickley, C., Warnaar, J., Williams, G., and Fuller, M.: Dinoflagellate cysts from the Eocene/Oligocene transition in the Southern Ocean; results from ODP Leg 189, Proceedings of the Ocean Drilling Program, Scientific Results, 189 1-42, https://doi.org/10.2973/odp.proc.sr.189.104.2003, 2003.

Sluijs, A., Pross, J., and Brinkhuis, H.: From greenhouse to icehouse; organic-walled dinoflagellate cysts as paleoenvironmental indicators in the Paleogene, Earth-Sci. Rev., 68, 281-315, https://doi.org/10.1016/j.earscirev.2004.06.001, 2005.

Stickley, C. E., Brinkhuis, H., Schellenberg, S. A., Sluijs, A., Röhl, U., Fuller, M., Grauert, M., Huber, M., Warnaar, J., and Williams, G. L.: Timing and nature of the deepening of the Tasmanian Gateway, Paleoceanography, 19, PA4027, https://doi.org/10.1029/2004pa001022, 2004a. 
Stickley, C. E, Brinkhuis, H., McGonigal, K., Chaproniere, G., Fuller, M., Kelly, D., Nürnberg, D., Pfuhl, H., Schellenberg, S., and Schönfeld, J.: Late Cretaceous-Quaternary biomagnetostratigraphy of ODP Sites 1168, 1170, 1171, and 1172, Tasmanian Gateway, Proceedings of the Ocean Drilling Program, Scientific Results, 189, 1-57, https://doi.org/10.2973/odp.proc.sr.189.111.2004, 2004b.

Stover, L., Brinkhuis, H., Damassa, S., De Verteuil, L., Helby, R., Monteil, E., Partridge, A., Powell, A., Riding, J., and Smelror, M.: Mesozoic-Tertiary dinoflagellates, acritarchs and prasinophytes, Palynology, 2, 641-750, 1996.

van Hinsbergen, D. J., de Groot, L. V., van Schaik, S. J., Spakman, W., Bijl, P. K., Sluijs, A., Langereis, C. G., and Brinkhuis, H.: A Paleolatitude Calculator for Paleoclimate Studies, PLoS One, 10, e0126946, https://doi.org/10.1371/journal.pone.0126946, 2015.

van Simaeys, S., Brinkhuis, H., Pross, J. r., Williams, G. L., and Zachos, J. C.: Arctic dinoflagellate migrations mark the strongest Oligocene glaciations, Geology, 33, 709-712, https://doi.org/10.1130/G21634.1, 2005.

Wall, D. and Dale, B.: "Living fossils" in western Atlantic plankton, Nature, 211, 1025-1026, 1966.

Wall, D., Dale, B., Lohmann, G., and Smith, W. K.: The environmental and climatic distribution of dinoflagellate cysts in modern marine sediments from regions in the North and South Atlantic Oceans and adjacent seas, Mar. Micropaleontol., 2, 121200, 1977.

Warny, S., Wrenn, J. H., Bart, P. J., and Askin, R.: Palynology of the NBP03-01A transect in the Northern Basin, western Ross Sea, Antarctica: A late Pliocene record, Palynology, 30, 151182, https://doi.org/10.1080/01916122.2006.9989624, 2006.

Warny, S., Kymes, C. M., Askin, R. A., Krajewski, K. P., and Bart, P. J.: Remnants of Antarctic vegetation on King George Island during the early Miocene Melville glaciation, Palynology, 40, 66-82, https://doi.org/10.1080/01916122.2014.999954, 2016.

Weatherall, P., Marks, K. M., Jakobsson, M., Schmitt, T., Tani, S., Arndt, J. E., Rovere, M., Chayes, D., Ferrini, V., and Wigley, R.: A new digital bathymetric model of the world's oceans, Earth Space Sci., 2, 331-345, https://doi.org/10.1002/2015EA000107, 2015.

Westerhold, T., Marwan, N., Drury, A. J., Liebrand, D., Agnini, C., Anagnostou, E., Barnet, J. S. K., Bohaty, S. M., De Vleeschouwer, D., Florindo, F., Frederichs, T., Hodell, D. A., Holbourn, A. E., Kroon, D., Lauretano, V., Littler, K., Lourens, L. J., Lyle, M., Palike, H., Rohl, U., Tian, J., Wilkens, R. H., Wilson, P. A., and Zachos, J. C.: An astronomically dated record of Earth's climate and its predictability over the last 66 million years, Science, 369, 1383-1387, https://doi.org/10.1126/science.aba6853, 2020.
Whittaker, J. M., Williams, S. E., and Müller, R. D.: Revised tectonic evolution of the Eastern Indian Ocean, Geochem. Geophy. Geosy., 14, 1891-1909, https://doi.org/10.1002/ggge.20120, 2013.

Williams, G. L., Fensome, R. A., and Macrae, R.: The Lentin and Williams index of fossil dinoflagellates 2017 Edition, American Association of Stratigraphic Palynologists Foundation (AASP), Contributions Series Number 48, Dallas, Texas, USA, 2017.

Williams, S. E., Whittaker, J. M., Halpin, J. A., and Müller, R. D.: Australian-Antarctic breakup and seafloor spreading: Balancing geological and geophysical constraints, Earth-Sci. Rev., 188, 4158, https://doi.org/10.1016/j.earscirev.2018.10.011, 2019.

Wrenn, J. H. and Beckman, S. W.: Maceral, total organic carbon, and palynological analyses of ross ice shelf project site j9 cores, Science, 216, 187-189, https://doi.org/10.1126/science.216.4542.187, 1982.

Young, J. R., Bown P. R., and Lees J. A.: mikrotax website. International Nannoplankton Association, available at: https://www. mikrotax.org (last access: 19 Juni 2019), 2017.

Zachos, J. C., Stott, L. D., and Lohmann, K. C.: Evolution of early Cenozoic marine temperatures, Paleoceanography, 9, 353-387, https://doi.org/10.1029/93PA03266, 1994.

Zonneveld, K. A. F., Versteegh, G. J. M., Kasten, S., Eglinton, T. I., Emeis, K. C., Huguet, C., Koch, B. P., de Lange, G. J., de Leeuw, J. W., Middelburg, J. J., Mollenhauer, G., Prahl, F. G., Rethemeyer, J., and Wakeham, S. G.: Selective preservation of organic matter in marine environments; processes and impact on the sedimentary record, Biogeosciences, 7, 483-511, https://doi.org/10.5194/bg-7-483-2010, 2010.

Zonneveld, K. A. F., Marret, F., Versteegh, G. J. M., Bogus, K., Bonnet, S., Bouimetarhan, I., Crouch, E., de Vernal, A., Elshanawany, R., Edwards, L., Esper, O., Forke, S., Grøsfjeld, K., Henry, M., Holzwarth, U., Kielt, J.-F., Kim, S.Y., Ladouceur, S., Ledu, D., Chen, L., Limoges, A., Londeix, L., Lu, S. H., Mahmoud, M. S., Marino, G., Matsouka, K., Matthiessen, J., Mildenhal, D. C., Mudie, P., Neil, H. L., Pospelova, V., Qi, Y., Radi, T., Richerol, T., Rochon, A., Sangiorgi, F., Solignac, S., Turon, J.-L., Verleye, T., Wang, Y., Wang, Z., and Young, M.: Atlas of modern dinoflagellate cyst distribution based on 2405 data points, Rev. Palaeobot. Palyno., 191, 1197, https://doi.org/10.1016/j.revpalbo.2012.08.003, 2013. 